\title{
SRS Type II HLW Tank 15 NDE Inspection Results
}

\author{
Author: J. B. Elder \\ Inspection Team: E. R. Holland, R. W. Vande Kamp, J. B. Elder \\ Savannah River Technology Center \\ NDE and Materials Reliability \\ Materials Technology Section
}

February 24, 2003

DOES NOT CONTAIN

UNCLASSIFIED CONTROLLED

NUCLEAR INFORMATION

ADC \&

Reviewing

Official:

Date:

\section{Westinghouse Savannah River Company Savannah River Site Aiken, SC 29808}

This document was prepared in connection with work done under Contract No. DE-AC09-96SR18500 with the U. S. Department of Energy 
This document was prepared in conjunction with work accomplished under Contract No. DE-AC09-96SR18500 with the U. S. Department of Energy.

\section{DISCLAIMER}

This report was prepared as an account of work sponsored by an agency of the United States Government. Neither the United States Government nor any agency thereof, nor any of their employees, makes any warranty, express or implied, or assumes any legal liability or responsibility for the accuracy, completeness, or usefulness of any information, apparatus, product or process disclosed, or represents that its use would not infringe privately owned rights. Reference herein to any specific commercial product, process or service by trade name, trademark, manufacturer, or otherwise does not necessarily constitute or imply its endorsement, recommendation, or favoring by the United States Government or any agency thereof. The views and opinions of authors expressed herein do not necessarily state or reflect those of the United States Government or any agency thereof.

This report has been reproduced directly from the best available copy.

Available for sale to the public, in paper, from: U.S. Department of Commerce, National Technical Information Service, 5285 Port Royal Road, Springfield, VA 22161, phone: (800) 553-6847, fax: (703) 605-6900

email: orders@ntis.fedworld.gov

online ordering: http://www.ntis.gov/help/index.asp

Available electronically at http://www.osti.gov/bridge

Available for a processing fee to U.S. Department of Energy and its contractors, in paper, from: U.S. Department of Energy, Office of Scientific and Technical Information, P.O. Box 62, Oak Ridge, TN 37831-0062,

phone: (865)576-8401,

fax: (865)576-5728

email: $\underline{\text { reports@ adonis.osti.gov }}$ 


\section{$\underline{\text { Table of Contents }}$}

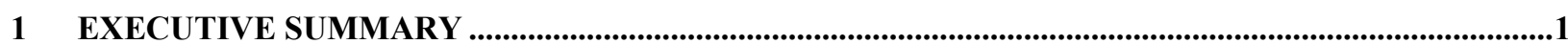

2 NDE INSPECTION REQUIREMENTS …...........................................................................................................

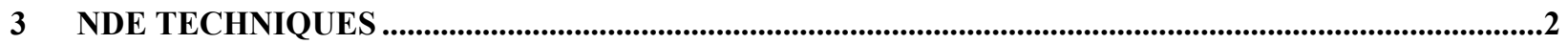

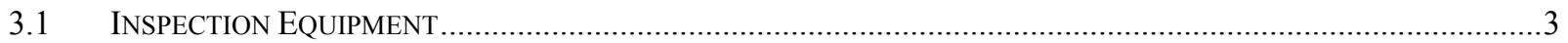

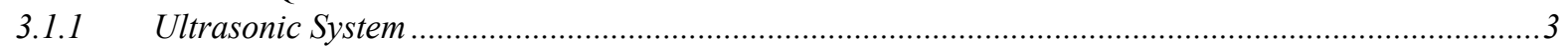

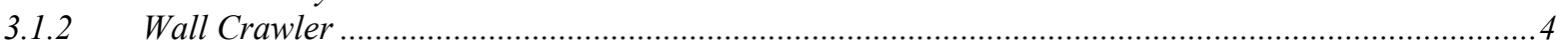

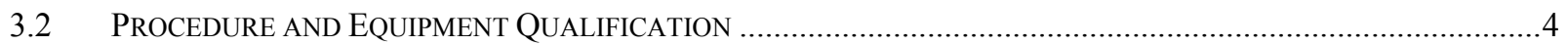

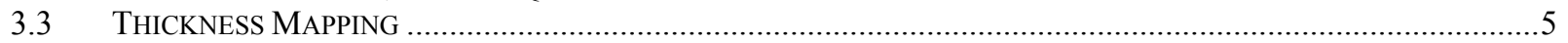

3.4 WELD INSPECTION AND CRACK DETECTION ..................................................................................

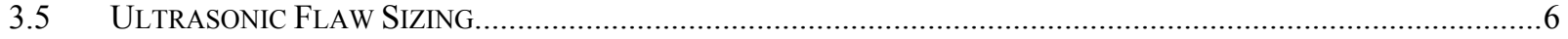

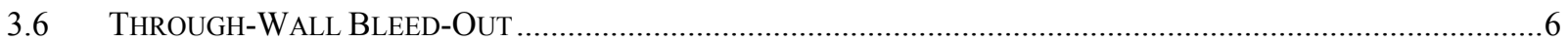

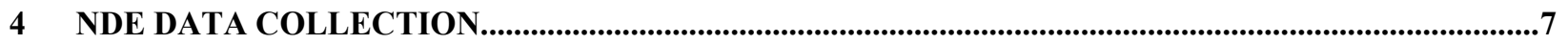

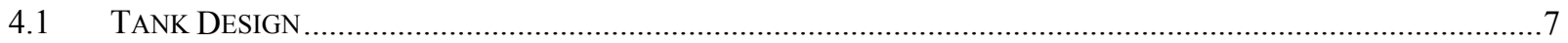

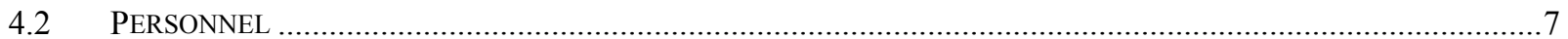

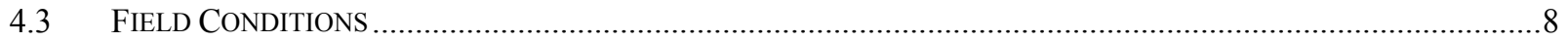

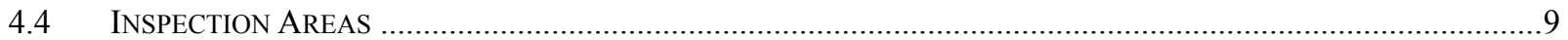

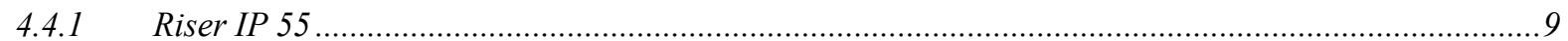

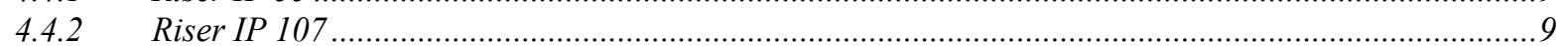

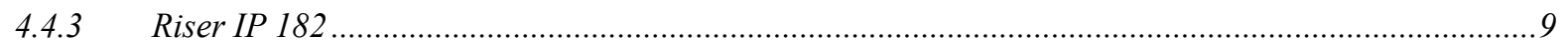

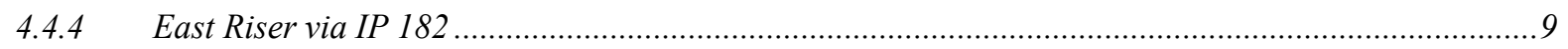

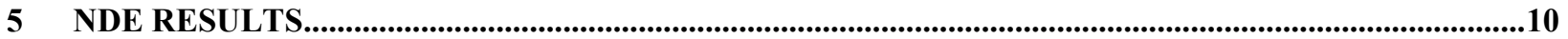

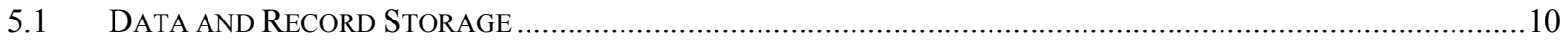

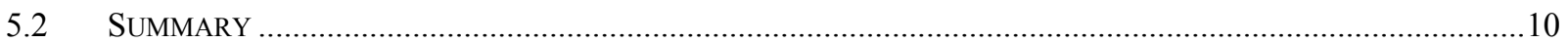

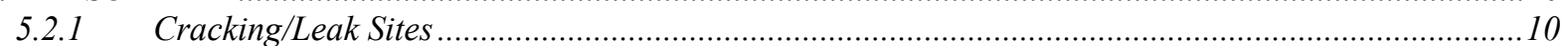

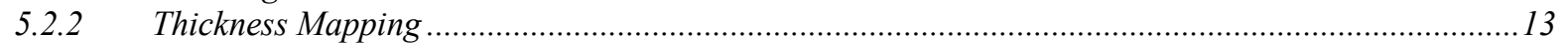

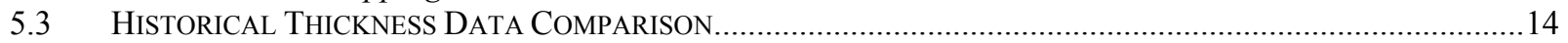

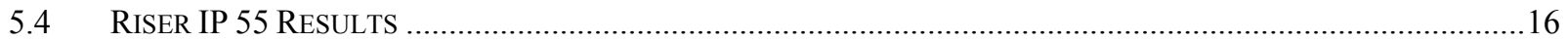

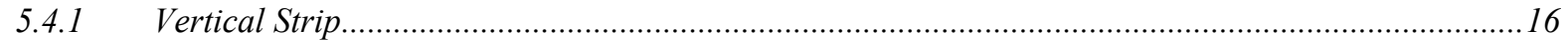

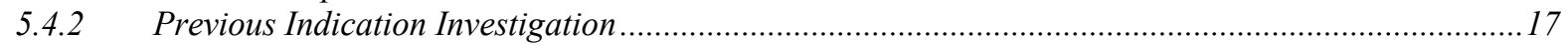

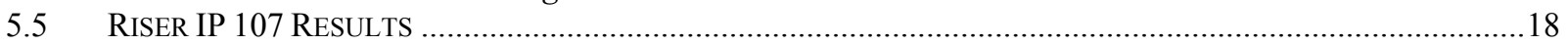

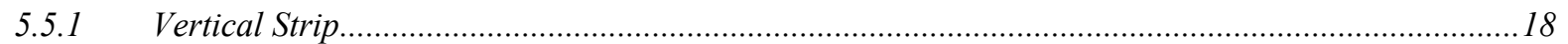

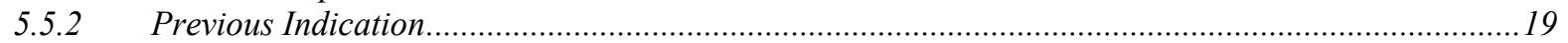

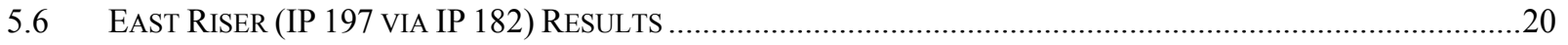

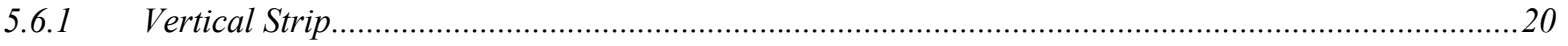

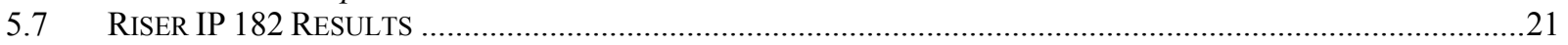

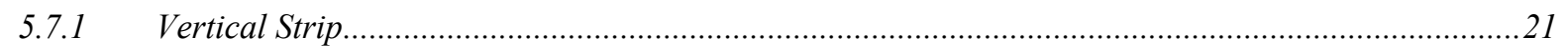

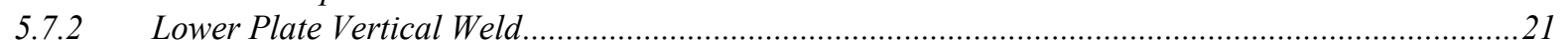

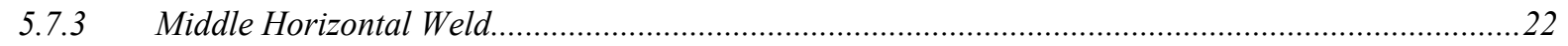

5.7.4 Leak Site at 172 feet, Middle Horizontal Weld ...............................................................................23

5.7.5 Leak Site at 192 feet, Middle Horizontal Weld ............................................................................24

5.7.6 Leak Site at 207 feet, Middle Horizontal Weld ..........................................................................25

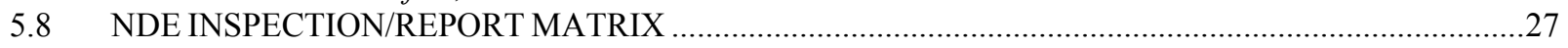

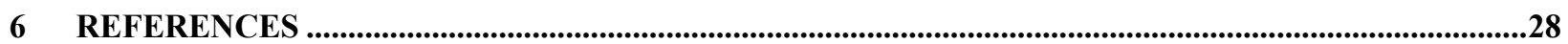




\section{$\underline{\text { List of Figures }}$}

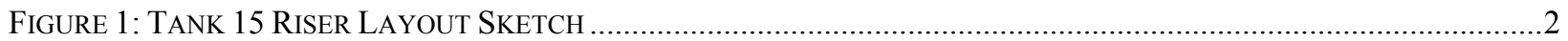

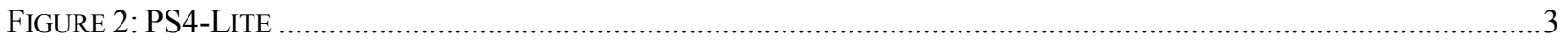

FIGURE 3: P-SCAN AMS-1T WALL CRAWLER.............................................................................................

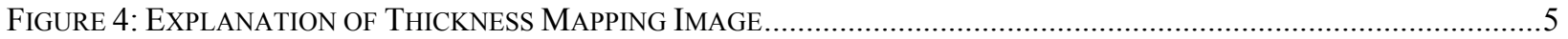

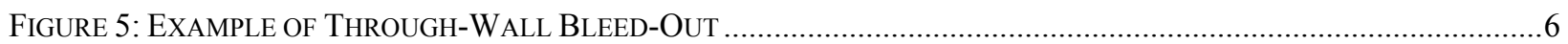

FIGURE 6: TYPE II HIGH LEVEL WASTE TANK .................................................................................

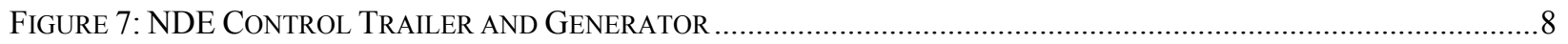

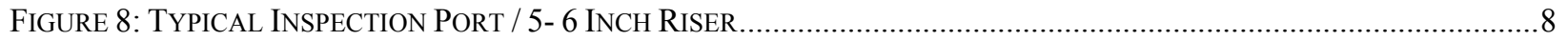

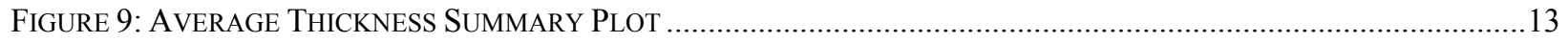

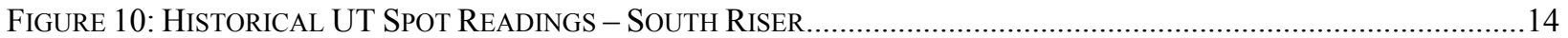

FigURE 11: AVERAGE THICKNESS MAPPING DATA VS INITIAL SPOT READING DATA..................................................15

FigURE 12: MINIMUM THICKNESS MAPPING DATA VS INITIAL SPOT READING DATA ……......................................15

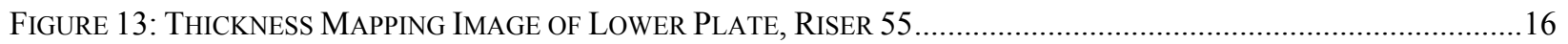

Figure 14: Visual IMAge of CRACK IN UpPer Plate VerTiCAL Weld, Riser 55 ..............................................17

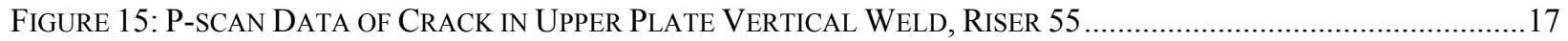

FigURE 16: THICKNESS MAPPING IMAGE OF LOWER PLATE, RISER 107...........................................................18

FiguRE 17: PictURE OF Mid Plate INDICATION AT ATTACHMENT, RiSER 107 ..........................................................19

FigURE 18: THICKNESS MAP OF THE LOWER PLATE VERTICAL STRIP, EAST RISER …....................................................20

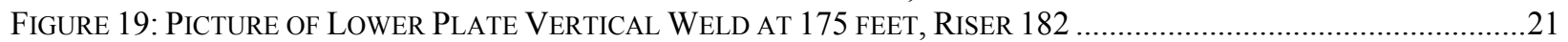

Figure 20: P-SCAN IMAge OF HoRizontal CRACK ACRoss VerTiCAL WELD AT 175 FEET ....................................22

FiguRE 21: THICKNESS MAP OF CRACK AT 172 FEET MidDLE HoRIZONTAL WELD ..................................................23

Figure 22: P-SCAN IMAGE OF Vertical Crack at 172 FEet, Middle Horizontal Weld ....................................22

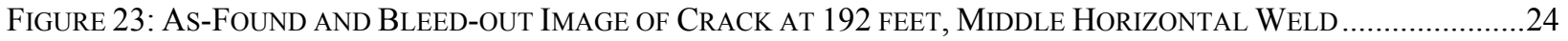

FigURE 24: P-SCAN IMAGE OF CRACK AT 192 FEeT, MidDLE HoRIZONTAL WELD ..................................................24

FIGURE 25: As-FoUND IMAGE OF INDICATION AT 207 FEET, MIDDLE HoRIZONTAL WELD .......................................25

FigURE 26: IMAGE OF WELD REPAIR AT 207 FEET MIDDLE WELD ......................................................................25

Figure 27: IMAGE WITH BLEEd-OUt FROM INDICATION AT 207 FEET, MidDLE HoRIZONTAL WELD..........................26

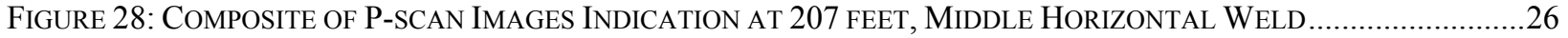

\section{$\underline{\text { List of Tables }}$}

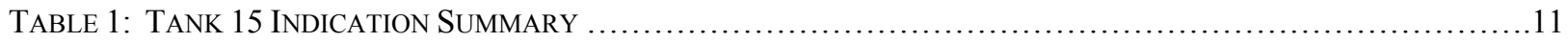

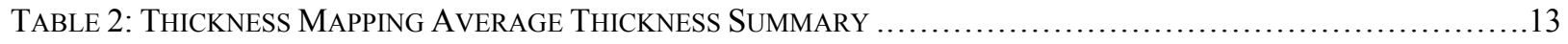




\section{EXECUTIVE SUMMARY}

This report provides a description of the ultrasonic (UT) nondestructive examinations (NDE) and the results of the examinations, performed on high level waste (HLW) storage tank number 15 at the Savannah River Site. These inspections were performed in accordance with the "In-Service Inspection (ISI) Program for High Level Waste Tanks" ${ }^{i}$ The ISI Program for HLW Tanks was developed using the "Guidelines for Tank Structural Integrity Programs" for waste tank in-service inspection programs ii as a guide.

The inspections were performed from the contaminated, annular space of the 46 year old, inactive, 1.03 million gallon waste storage tank. A steerable, magnetic wheel wall crawler was used to simultaneously collect data with up to 4 UT transducers and 2 cameras.

The purpose of this inspection was to verify known corrosion models and to investigate the possibility of previously unidentified corrosion mechanisms. The inspections included evaluation of previously identified leak sites as well as thickness mapping and crack detection scans on specified areas of the tank covering welds and all past and present interface levels.

No indications of reportable wall loss or pitting were detected. All thickness readings were above minimum design thickness. Several small indications of thinning were detected. The crack detection and sizing examinations detected five previously undetected indications, four of which were only partially through wall. The cracks that were examined were found to be slightly longer than expected, but are still well within the critical flaw size criteria.

The HLW ISI Review Committee requested the Materials Performance and Corrosion Technology group of Savannah River Technology Center (SRTC) to evaluate the structural impact of these findings. The results of these evaluations are reported in WSRC-TR-2002-00590. ${ }^{\text {iii }}$

\section{NDE INSPECTION REQUIREMENTS}

The ISI Program for HLW Tanks stipulates the frequency and extent of the areas to be examined, as well as the damage mechanism(s) to be detected. The ISI Program for HLW Tanks states: "Tank 15 shall be inspected two times within a five-year time span to validate current degradation models. Known leak sites will be characterized in addition to the normal extent of examination. If leakage occurs in unexpected regions and unknown degradation mechanisms are suspected, additional inspections will be performed."

The ISI Program for HLW Tanks calls for the following regions of a HLW tank to be inspected:

- Liquid Vapor Interface

- Liquid Sludge Interface

- Upper Weld of Lower Knuckle of Primary Tank (5\% of accessible circumference)

- Lower Knuckle Base Material

- External surface of primary tank (includes vapor space)

- Vertical and horizontal welds other than the lower knuckle weld (one vertical course section and 5\% of middle horizontal weld)

These general requirements are further delineated in an inspection plan for the specific tank to be inspected. Tank 15 was inspected in accordance with "HLWE-STE-2002-00258, CSTE UT Inspection Plan for Tank 15 ,iv which stipulates the following inspections specific to the primary wall of tank 15:

1. Four vertical strips for the entire accessible height of the tank one each under riser IP55, IP107, IP182 and the East riser (see Figure 1).

2. 30 feet of middle horizontal weld between riser IP171 and IP207 (10\% of circumference additional $5 \%$ in lieu of $5 \%$ of upper weld of lower knuckle which was inaccessible due to tank geometry.)

3. Lower primary shell plate vertical weld below riser IP182 
4. Five previously identified leak sites:

- vertical weld at 53 feet, 200 inches above tank bottom

- lower primary shell plate at 115 feet, 88 inches above tank bottom

- middle horizontal weld at 172 feet

- middle horizontal weld at 192 feet

- middle horizontal weld at 207 feet

The following figure illustrates the approximate radial location of annulus access risers. Locations are in feet from the South riser. The North, South, East and West risers are 5 inch carbon steel pipe. The other inspection ports (IP) were added using a 6 inch diameter core drill.

\section{Figure 1: Tank 15 Riser Layout Sketch}

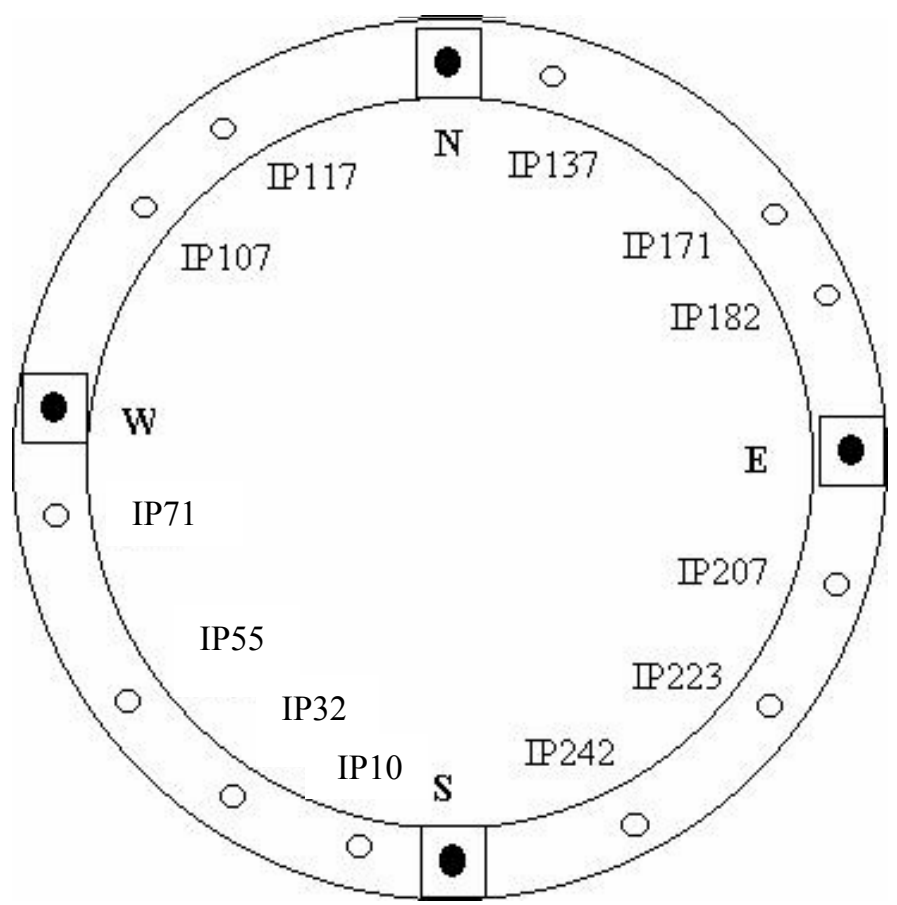

\section{NDE TECHNIQUES}

NDE inspection of tank 15 included remote automated ultrasonic inspection supplemented by remote visual inspection. Inspection of Tank 15 included the following techniques which are described in this section:

1. Thickness Mapping

2. Weld Inspection/Crack Detection

3. Ultrasonic Flaw Sizing

4. Through Wall Bleed-out 


\subsection{Inspection Equipment}

All ultrasonic inspections were performed utilizing the P-scan, automated ultrasonic system and remotely operated magnetic wheel scanner known as the wall crawler. The prescribed regions were inspected utilizing two basic data collection techniques:

1. Vertical Strips - base material thickness mapping and crack detection scans, and

2. Weld Inspection - scans of weld and heat affected zones to detect and characterize cracking oriented parallel and/or perpendicular to the weld seam.

\subsubsection{Ultrasonic System}

The UT system utilized for these inspections was the FORCE Technology, P-scan, PS4-Lite, automated, ultrasonic system. This system is capable of performing inspections with multiple transducers and techniques simultaneously.

The PS4-Lite is basically the same as the PS4, except that it can not operate more than 4 transducers simultaneously. It is capable of performing thickness mapping, weld inspection and A-scan recording all at the same time. During tank inspections it was used to operate 2 angle beam and 1 thickness mapping transducer or 4 angle beam probes simultaneously.

The PS4Lite is operated through a laptop computer as the user interface.

The system also controls the wall crawler.

Figure 2: PS4-Lite

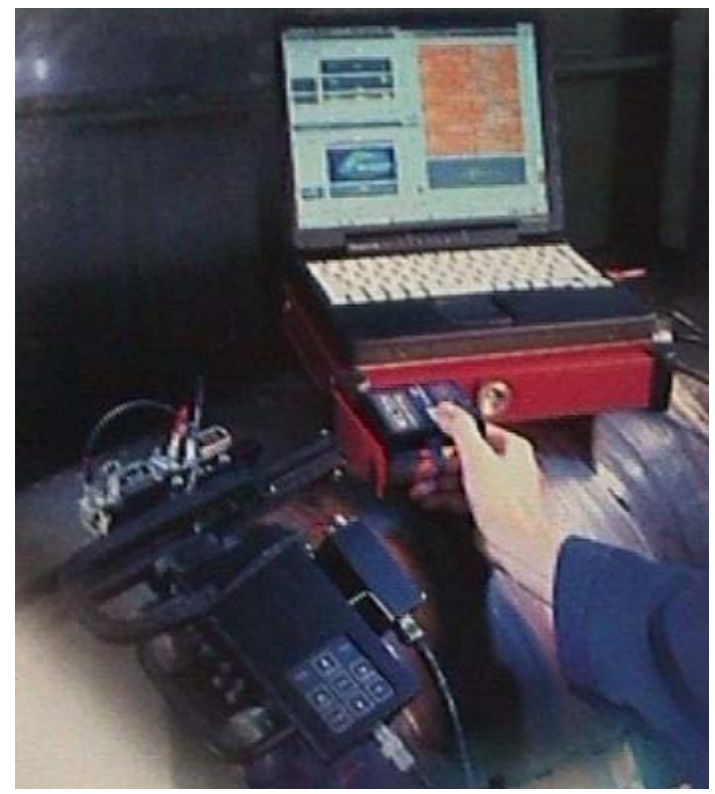




\subsubsection{Wall Crawler}

The wall crawler is a commercially available, FORCE Technology, P-scan , AMS-1T crawler. The crawler is attached to the steel tank wall by the strong, permanent magnetic wheels.

The crawler is capable of being installed through a five inch carbon steel riser. It can scan with up to 4 transducers. The wall crawler is typically outfitted with a remote control pan and tilt camera system with auxiliary lighting.

The wall crawler included a pneumatically activated camera boom arm to lift the pan and tilt camera about 10 inches off the surface. It also has pneumatic lifting feet to de-couple it from the tank wall to allow removal from the annulus.

Figure 3: P-scan AMS-1T Wall Crawler

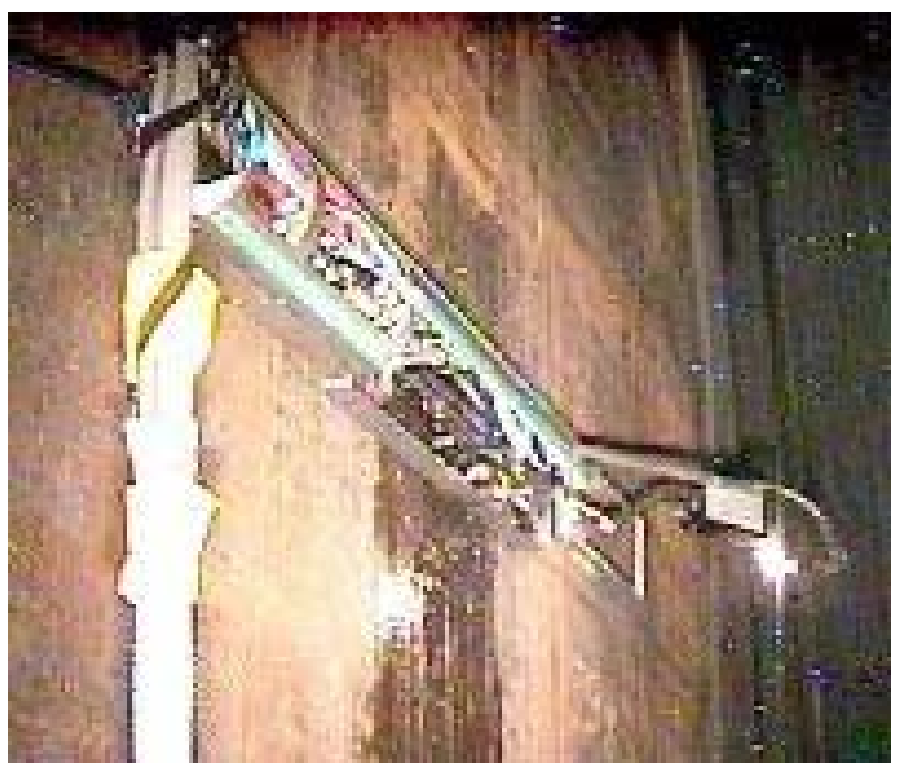

\subsection{Procedure and Equipment Qualification}

The NDE procedures and equipment utilized for thickness mapping and weld inspection were qualified to the requirements of the ISI Program for HLW Tanks prior to performing inspections in the tank. The ISI Program for HLW Tanks states that the UT system (instrument, transducer, scanning device, and cables) shall have the following detection limits (tested at $1 / 2$ inch nominal thickness):

1. General corrosion/thinning detection within 0.020 inch.

2. Pitting detection within 0.050 inch. (elliptical or hemispherical)

3. Crack depth detection within 0.100 inch, $\geq 0.5$ inch long, $<6$ inches long. In the absence of an acceptable cracked sample, a machined notch 0.05 inch deep $x 1$ inch long can be used instead of a crack.

The procedures and equipment met the above requirements. ${ }^{v}$ 


\subsection{Thickness Mapping}

Thickness mapping includes wall thickness measurement as well as the detection and sizing of corrosion, pitting, and interface attack. Thickness mapping was performed in four vertical strips. Individual vertical strips were 8.5 inches wide so the combined width of all 4 strips provided coverage of $1 \%$ of the circumference of the tank. Thickness mapping data was collected over the entire accessible height of the tank to ensure coverage of all areas and environments in the tank. By collecting data in a continuous strip from top to bottom, all present and historic interface levels are examined as well as the vapor space of the tank.

Thickness mapping data was collected utilizing the FORCE Institutes, P-scan PS4 (Lite) automated ultrasonic system. The "T-scan" thickness mapping program was utilized to provide color-coded thickness plots from the top, side and end views. This data was collected utilizing a dual element, 0 degree, longitudinal wave transducer (Krautkramer DA301) operating at $5 \mathrm{MHz}$. Figure 4 provides an explanation of the thickness mapping data.

Figure 4: Explanation of Thickness Mapping Image

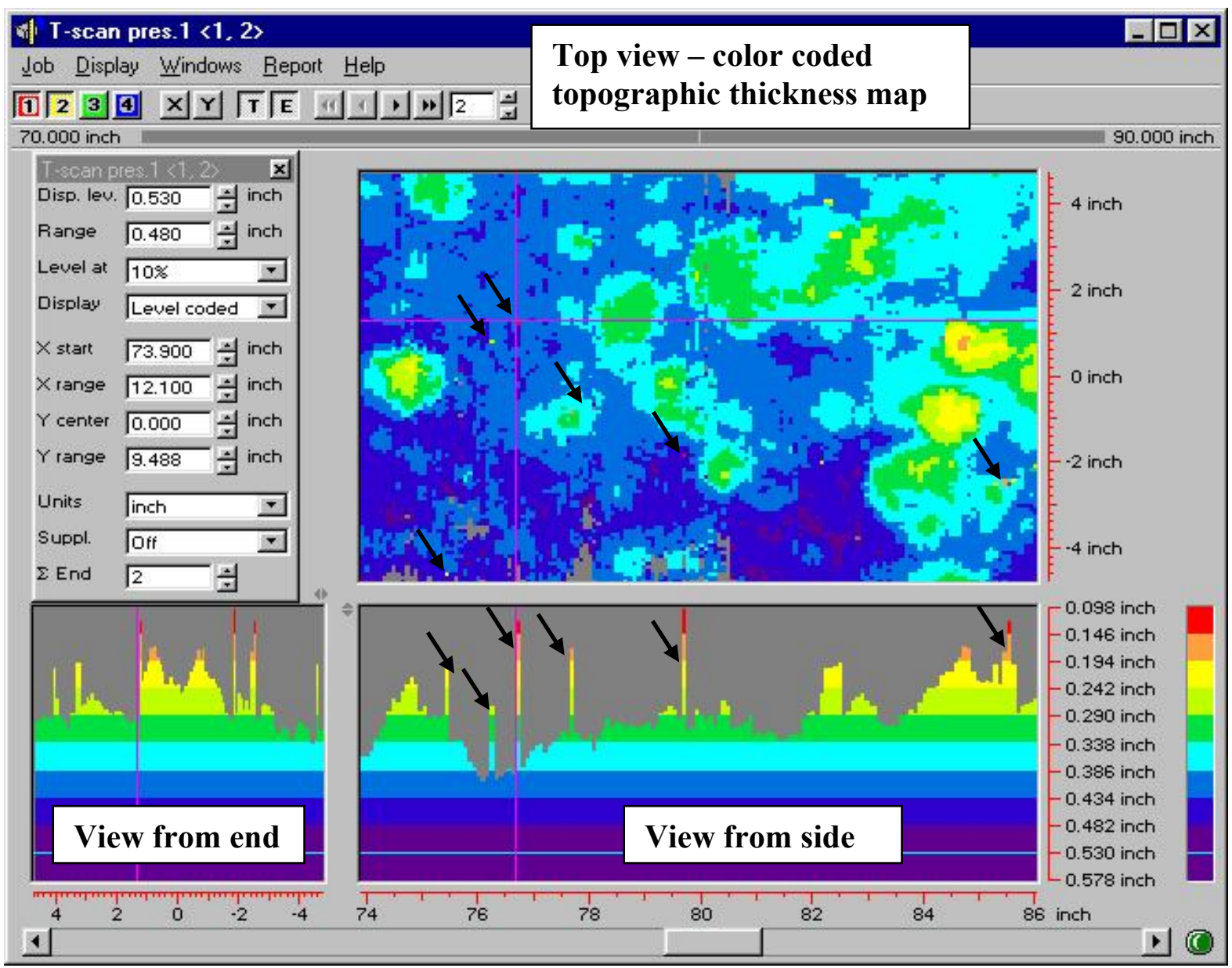

This figure shows actual thickness mapping data collected on a carbon steel sample. This sample data shows actual pitting corrosion in a carbon steel pipe sample at the liquid vapor interface. The image shows pitting and corrosion patterns typical of actual wall loss as well as noise spikes (also known as data dropout). The noise spikes are noted with arrows in the top and side views. 


\subsection{Weld Inspection and Crack Detection}

Weld Inspection and crack detection were performed with the same ultrasonic system utilizing the "Pscan" amplitude based weld inspection software. Crack detection was performed utilizing single element, 45 degree shear wave transducers (Krautkramer MWB-45-4E) operating at $4 \mathrm{MHz}$. This technique was incorporated into the thickness mapping vertical strips and was utilized to examine welds for cracking oriented parallel and perpendicular to the weld seam.

\subsection{Ultrasonic Flaw Sizing}

When indications were detected with ultrasonic techniques, the extent of the indications were measured or "sized". The location and length/width in the X and Y directions were determined based on where the indication was discernable from the background noise or thickness.

1. Pitting indications were reported based on remaining, sound, metal (ligament) above the pit. The depth of any pit indications was determined by subtracting the minimum thickness reading obtained from the pit from the thickness of the area adjacent to the pit.

2. Cracking lengths were reported to the point(s) where the indication was no longer discernable from the noise. Crack depths were determined utilizing planar flaw sizing techniques. Utilizing the same transducer(s) that were used for detection, the amplitude was adjusted to locate the deepest point on the crack. When indications were less than 100 percent through wall, a measurement of the remaining metal (ligament) was made utilizing the Absolute Arrival Time Technique (AATT). AATT is a planar flaw sizing technique, used throughout industry that provides a direct reading of depth to the crack tip.

\subsection{Through-Wall Bleed-Out}

Through-wall bleed-out is the term being used to describe the field implemented variation of a liquid penetrant surface inspection technique. It was noted that the water being used for UT couplant, would penetrate (through capillary action) surface cracks. Due to the elevated temperature of the tank wall ( 120 degrees F), the wetted surface would dry after a few minutes. Where there was a crack open to the exterior surface, the water drawn into the crack would then bleed out providing a high contrast image of the open crack. Video cameras were utilized to view these indications and make crude measurements of length as the crawler was driven along the indication(s).

\section{Figure 5: Example of Through-Wall Bleed-Out}

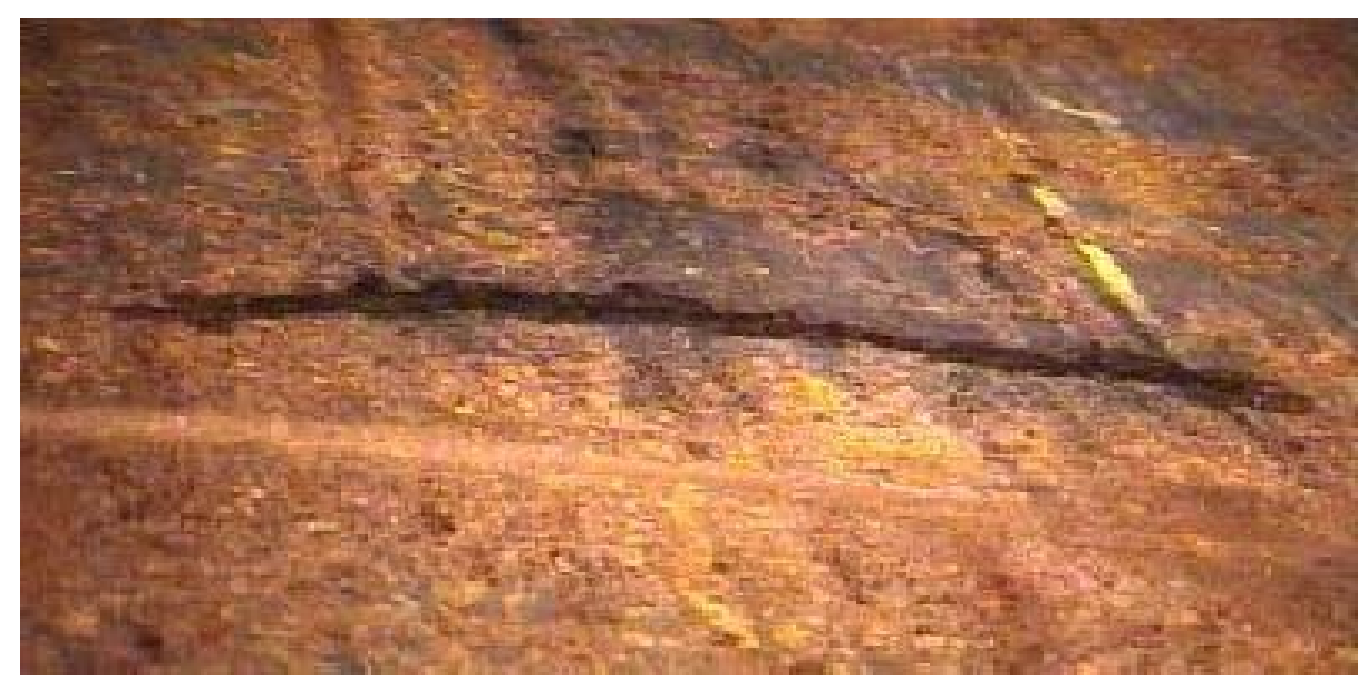




\section{NDE DATA COLLECTION}

\subsection{Tank Design}

Tank 15 is a Type II tank. Tank specifics are as follows:

- $\quad$ Constructed - 1955 through 1956, Entered service in 1960.

- $\quad$ Capacity - 1,030,000 gallons

- $\quad$ Material - ASTM A285, Grade B Carbon Steel (Not stress relieved)

- $\quad$ Construction Code - ASME-52

- $\quad$ Project Number - 8980 PWO

- $\quad$ Five 5-foot steel secondary containment pan. Material is A285, Grade B carbon steel

- Annulus Ventilation - Normally positive pressure (changed to negative during inspection)

- $\quad$ Annulus Access - Constructed with five inch carbon steel risers at the South, West, North and East annulus risers. Additional access provided through 6 inch diameter drilled inspection ports (IP). There are 12 IP's plus the four 5 inch risers spaced around the 267 foot circumference of the tank. The IP's are identified by the distance in feet from the South riser (see Figure 1)

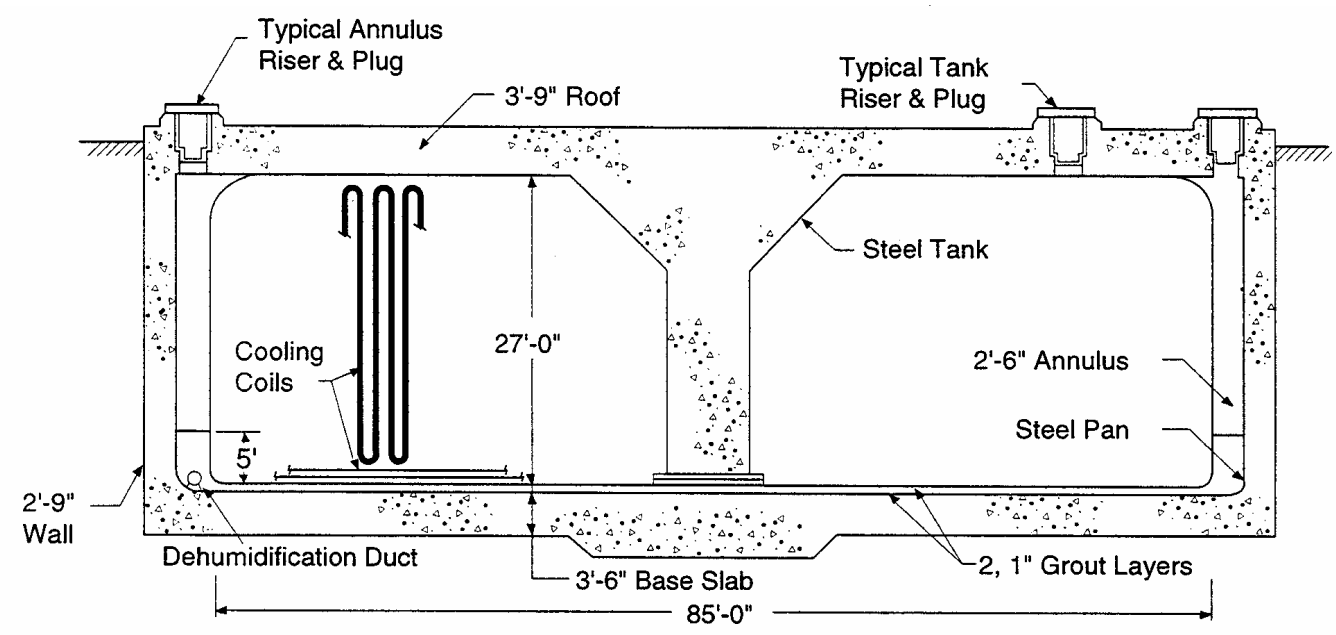

Figure 6: Type II High Level Waste Tank

\subsection{Personnel}

Nondestructive examination data was collected and analyzed by certified NDE personnel from the SRTC NDE and Materials Reliability group, including James B. Elder, ASNT Level III UT, Richard Holland and Rodney Vande Kamp both certified Level II UT.

HLW/CSTE, HLWM SMART group, HLW Operations and Radiation Control personnel also assisted in the field inspections. 


\subsection{Field Conditions}

Inspections were performed from the annular space of the high level waste tank. The wall crawler and cameras were installed in the annulus and operated from the NDE control trailer (see Figure 7) which was up to 200 feet from the riser. Access to the annulus was through inspection ports or risers (see Figure 8) inside contamination control huts. These risers are approximately four feet long and are either five inch carbon steel pipe or six inch diameter concrete holes. All UT inspections were performed by inserting the wall crawler through the six inch concrete risers. Remote pan \& tilt cameras were also inserted into the annulus to monitor crawler movement. Tank 15 has a history of through wall leaks, therefore the annulus is contaminated. The tank ventilation was shut down and auxiliary ventilation (MAC-21) was installed to provide negative pressure ventilation during the inspections. Huts were set up around each riser that was used for crawler access to provide contamination control. In addition to the huts and ventilation, respiratory protection was typically required during crawler installation, removal and maintenance activities.

Figure 7: NDE Control Trailer and Generator

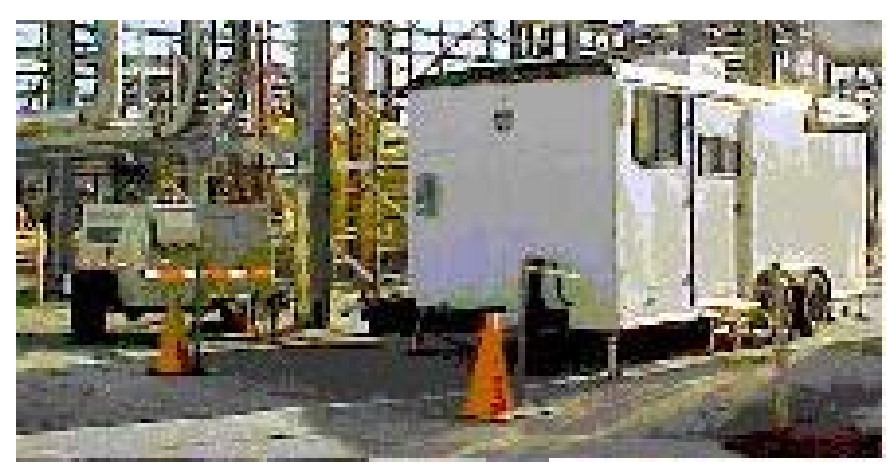

Figure 8: Typical Inspection Port / 5- 6 Inch Riser

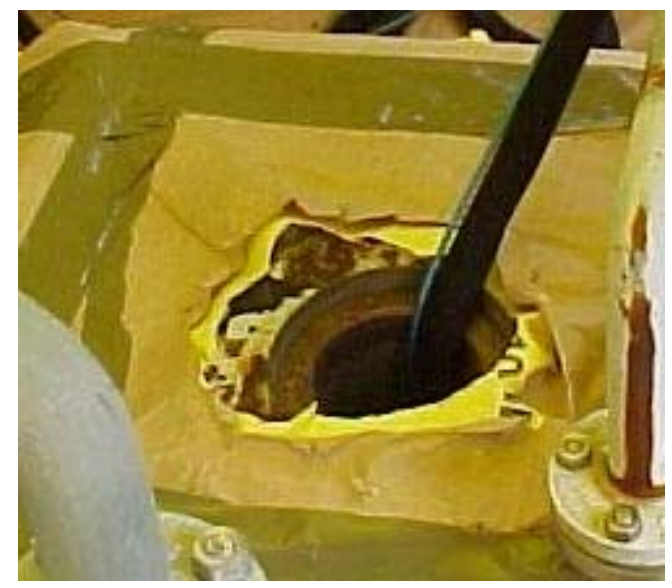




\subsection{Inspection Areas}

All of the required inspections were performed by deploying the crawler through three risers. UT inspections were performed with the wall crawler in riser IP55, IP 107 and riser IP 182.

The scope of the inspections were performed as follows:

\subsubsection{Riser IP 55}

- One vertical strip directly under the riser. The vertical strip was 8.5 inch wide and included inspections for thinning, pitting and vertically oriented cracking.

- One previously identified horizontal crack in the upper vertical weld was also examined.

\subsubsection{Riser IP 107}

- One vertical strip directly under the riser. The vertical strip was 8.5 inch wide and included inspections for thinning, pitting and vertically oriented cracking.

- One previously identified crack in the middle of the lower primary shell plate was also examined. (Determined to be attachment weld)

\subsubsection{Riser IP 182}

- One vertical strip directly under the riser. The vertical strip was 8.5 inch wide and included inspections for thinning, pitting and vertically oriented cracking.

- One vertical weld in the lower shell plate- only partial coverage was possible due to weld crown geometry.

- Middle Horizontal Weld - Examined approximately 33 feet for vertical and horizontal cracking. Also examined three previously identified leak sites:

1. Leak site at 172 feet, vertical crack in horizontal weld near lower plate vertical weld

2. Leak site at 192 feet, horizontal/arched crack in lower plate at repair weld location

3. Leak site at 207 feet, horizontal/arched crack at repair weld location

\subsubsection{East Riser via IP 182}

- One vertical strip directly under the riser. The vertical strip was 8.5 inch wide and included inspections for thinning, pitting and vertically oriented cracking. This riser was inspected with the crawler being inserted in Riser 182 and the camera in the East riser. 


\section{NDE RESULTS}

Inspection data was analyzed by certified NDE Level III personnel and presented to the ISI Review Committee prior to acceptance. The In-Service Inspection Review Committee (ISIRC) included representatives from HLWD/CSTE, HLWD/Plant Engineering, HLWD/Operations, SRTC/Materials Technology Section and DOE/HLW. A summary of NDE results was presented to the ISI Review Committee at the completion of data analysis for each riser. The function of the ISIRC was to review the data and determine if any additional data was required from that riser, prior to moving to the next. HLW ISI Review Committee Reports were written and signed at each meeting.

\subsection{Data and Record Storage}

NDE data sheets, P-scan data files and video tapes are stored in the NDE group records room under NDE Job \# H20020592.

\subsection{Summary}

Tank 15 is a Type II High Level Waste storage tank. This style of tank was not stress relieved and has a history of Stress Corrosion Cracking (SCC). Tank 15 is an inactive tank and has 18 previously identified leak sites. ${ }^{\mathrm{vi}}$

The inspections were performed from the annular space of the 46 year old, 1.03 million gallon waste storage tank. A steerable, magnetic wheel wall crawler was used to simultaneously collect data with up to 4 UT transducers and 2 cameras. The inspections were performed as part of the ISI Program for HLW Tanks and to gather additional data for material reliability studies.

\subsubsection{Cracking/Leak Sites}

Several leak sites were selected to be ultrasonically evaluated to determine the length, depth and contributing factors e.g., weld attachments, weld beads, etc.). These indications are scheduled for reinspection in five years to look for any changes and to evaluate crack growth (see Table 1). Maximum crack lengths were determined to be longer than previously expected but still well within the established critical crack length criteria.

Table 1 provides a summary of all known leak sites and crack-like indications at the conclusion of inspections in 2002. The table includes results from 2002 and previously identified indications that were not evaluated as part of the inspections documented in this report. 
TABLE 1 TANK 15 IndiCATION SUMMARY

\begin{tabular}{|c|c|c|c|c|c|c|}
\hline $\begin{array}{l}\text { Location } \\
\text { Feet From } \\
\text { South Riser / } \\
\text { Primary } \\
\text { NDE } \\
\text { method(s) }\end{array}$ & $\begin{array}{l}\text { Elevation } \\
\text { Height (in.) } \\
\text { from Primary } \\
\text { Tank Bottom }\end{array}$ & Item & $\begin{array}{l}\text { Indication } \\
\text { Type }\end{array}$ & $\begin{array}{l}\text { Through-wall } \\
\text { Wall Loss } \\
\text { from ID }\end{array}$ & $\begin{array}{l}\text { Horizontal } \\
\text { Measured } \\
\text { dimension } \\
\text { related to tank } \\
\text { horizontal }\end{array}$ & $\begin{array}{l}\text { Vertical } \\
\text { Measured } \\
\text { dimension } \\
\text { related to } \\
\text { tank vertical }\end{array}$ \\
\hline $\begin{array}{l}14 \\
\text { VT }\end{array}$ & $150^{\prime \prime}$ & $\begin{array}{l}\text { Middle } \\
\text { weld }\end{array}$ & $\begin{array}{l}\text { Leak site } \\
\text { Visual only }\end{array}$ & Leak site & $\mathrm{N} / \mathrm{A}$ & $\mathrm{N} / \mathrm{A}$ \\
\hline $\begin{array}{l}47^{\prime} \\
\text { VT }\end{array}$ & $\sim 30^{\prime \prime}$ & $\begin{array}{l}\text { Bottom } \\
\text { knuckle } \\
\text { weld }\end{array}$ & $\begin{array}{l}\text { Leak site } \\
\text { Visual only }\end{array}$ & Leak site & $\mathrm{N} / \mathrm{A}$ & $\mathrm{N} / \mathrm{A}$ \\
\hline $\begin{array}{l}53^{\prime} \\
\text { UT and VT }\end{array}$ & $200 "$ & $\begin{array}{l}\text { Upper } \\
\text { plate } \\
\text { vertical } \\
\text { weld } \\
\end{array}$ & $\begin{array}{l}\text { Horizontal } \\
\text { crack }\end{array}$ & $\begin{array}{l}\text { Leak Site } \\
100 \% \\
\text { through-wall } \\
\text { (TW) }\end{array}$ & $\begin{array}{l}\text { One sided } \\
3.7 " \text { this side, } \\
1.4 \text { TW }\end{array}$ & $\mathrm{N} / \mathrm{A}$ \\
\hline $\begin{array}{l}102^{\prime} \\
\text { VT }\end{array}$ & $\sim 30^{\prime \prime}$ & $\begin{array}{l}\text { Bottom } \\
\text { knuckle } \\
\text { weld }\end{array}$ & $\begin{array}{l}\text { Leak site } \\
\text { Visual only }\end{array}$ & Leak site & N/A & N/A \\
\hline $\begin{array}{l}105^{\prime} \\
\text { VT }\end{array}$ & $126^{\prime \prime}$ & $\begin{array}{l}\text { Lower } \\
\text { plate } \\
\text { vertical } \\
\text { weld } \\
\end{array}$ & $\begin{array}{l}\text { Leak site } \\
\text { Visual only }\end{array}$ & Leak site & $\mathrm{N} / \mathrm{A}$ & $\mathrm{N} / \mathrm{A}$ \\
\hline $\begin{array}{l}112^{\prime} \\
\text { VT }\end{array}$ & $\sim 30 "$ & $\begin{array}{l}\text { Bottom } \\
\text { knuckle } \\
\text { weld }\end{array}$ & $\begin{array}{l}\text { Leak site } \\
\text { Visual only }\end{array}$ & Leak site & N/A & $\mathrm{N} / \mathrm{A}$ \\
\hline $\begin{array}{l}115^{\circ} \\
\text { UT and VT }\end{array}$ & $88 "$ & $\begin{array}{l}\text { Lower } \\
\text { plate } \\
\text { Mid-plate } \\
\text { attachm- } \\
\text { ent weld }\end{array}$ & $\begin{array}{l}\text { Arched crack } \\
\text { at external } \\
\text { attachment }\end{array}$ & $\begin{array}{l}\text { Leak site } \\
100 \% \\
\text { through-wall } \\
\text { (TW) }\end{array}$ & $\begin{array}{l}\text { Partially } \\
\text { obstructed } \\
\text { measured 2.3" }\end{array}$ & $\begin{array}{l}\text { Partially } \\
\text { obstructed } \\
\text { measured } \\
3.7 \text { " }\end{array}$ \\
\hline $\begin{array}{l}136^{\prime} \\
\text { VT }\end{array}$ & $\sim 30 "$ & $\begin{array}{l}\text { Bottom } \\
\text { knuckle } \\
\text { weld }\end{array}$ & $\begin{array}{l}\text { Leak site } \\
\text { Visual only }\end{array}$ & Leak site & N/A & N/A \\
\hline $\begin{array}{l}139^{\prime} \\
\text { VT }\end{array}$ & $\sim 30^{\prime \prime}$ & $\begin{array}{l}\text { Bottom } \\
\text { knuckle } \\
\text { weld }\end{array}$ & $\begin{array}{l}\text { Leak site } \\
\text { Visual only }\end{array}$ & Leak site & $\mathrm{N} / \mathrm{A}$ & $\mathrm{N} / \mathrm{A}$ \\
\hline $\begin{array}{l}144^{\prime} \\
\text { VT }\end{array}$ & $\sim 30^{\prime \prime}$ & $\begin{array}{l}\text { Bottom } \\
\text { knuckle } \\
\text { weld }\end{array}$ & $\begin{array}{l}\text { Leak site } \\
\text { Visual only }\end{array}$ & Leak site & N/A & N/A \\
\hline $\begin{array}{l}159^{\prime} \\
\text { VT }\end{array}$ & $150 "$ & $\begin{array}{l}\text { Middle } \\
\text { horizontal } \\
\text { weld }\end{array}$ & $\begin{array}{l}\text { Leak site } \\
\text { Visual only }\end{array}$ & Leak site & $\mathrm{N} / \mathrm{A}$ & $\mathrm{N} / \mathrm{A}$ \\
\hline $\begin{array}{l}172 \\
\text { UT and VT }\end{array}$ & $150 "$ & $\begin{array}{l}\text { Middle } \\
\text { horizontal } \\
\text { weld }\end{array}$ & Vertical crack & $\begin{array}{l}\text { Leak Site } \\
100 \% \\
\text { through-wall } \\
\text { (TW) }\end{array}$ & N/A & $\begin{array}{l}\text { 7" TW, 7.9" } \\
\text { total length. } \\
\text { *May be } 10.7 \\
\text { combined }\end{array}$ \\
\hline $\begin{array}{l}172^{\prime} \\
\text { VT }\end{array}$ & $68 "$ & $\begin{array}{l}\text { Lower } \\
\text { plate } \\
\text { Vertical } \\
\text { weld }\end{array}$ & $\begin{array}{l}\text { Leak site } \\
\text { Visual only }\end{array}$ & Leak site & $\mathrm{N} / \mathrm{A}$ & $\mathrm{N} / \mathrm{A}$ \\
\hline
\end{tabular}




\section{TABLE 1: TANK 15 INDICATION SUMmaRy (CONTINUED)}

\begin{tabular}{|c|c|c|c|c|c|c|}
\hline $\begin{array}{l}\text { Location } \\
\text { Feet From } \\
\text { South Riser / } \\
\text { Primary } \\
\text { NDE } \\
\text { method(s) } \\
\end{array}$ & $\begin{array}{l}\text { Elevation } \\
\text { Height (in.) } \\
\text { from Primary } \\
\text { Tank Bottom }\end{array}$ & Item & Indication type & $\begin{array}{l}\text { Through-wall } \\
\text { Wall Loss } \\
\text { from ID }\end{array}$ & $\begin{array}{l}\text { Horizontal } \\
\text { Measured } \\
\text { dimension } \\
\text { related to tank } \\
\text { horizontal }\end{array}$ & $\begin{array}{l}\text { Vertical } \\
\text { Measured } \\
\text { dimension } \\
\text { related to } \\
\text { tank vertical }\end{array}$ \\
\hline $\begin{array}{l}1722^{\prime} 6^{\prime \prime} \\
\text { VT }\end{array}$ & $\sim 30^{\prime \prime}$ & $\begin{array}{l}\text { Bottom } \\
\text { knuckle } \\
\text { weld }\end{array}$ & $\begin{array}{l}\text { Leak site } \\
\text { Visual only }\end{array}$ & Leak site & $\mathrm{N} / \mathrm{A}$ & $\mathrm{N} / \mathrm{A}$ \\
\hline $\begin{array}{l}174^{\prime} 6 " \\
\text { VT }\end{array}$ & $\sim 30 "$ & $\begin{array}{l}\text { Bottom } \\
\text { knuckle } \\
\text { weld }\end{array}$ & $\begin{array}{l}\text { Leak site } \\
\text { Visual only }\end{array}$ & Leak site & N/A & N/A \\
\hline $\begin{array}{l}175^{\prime} \\
\text { UT data }\end{array}$ & $139 "$ & $\begin{array}{l}\text { Lower } \\
\text { plate } \\
\text { vertical } \\
\text { weld } \\
\end{array}$ & $\begin{array}{l}\text { Horizontal } \\
\text { crack-like } \\
\text { indication }\end{array}$ & $<25 \%$ & $1.2 "$ & $\mathrm{~N} / \mathrm{A}$ \\
\hline $\begin{array}{l}175^{\prime} \\
\text { UT data }\end{array}$ & $129 "$ & $\begin{array}{l}\text { Lower } \\
\text { plate } \\
\text { vertical } \\
\text { weld }\end{array}$ & $\begin{array}{l}\text { Horizontal } \\
\text { crack-like } \\
\text { indication }\end{array}$ & $100 \% \mathrm{TW}$ & $4.5 "$ & N/A \\
\hline $\begin{array}{l}175^{\prime} \\
\text { UT data }\end{array}$ & $51 "$ & $\begin{array}{l}\text { Lower } \\
\text { plate } \\
\text { vertical } \\
\text { weld }\end{array}$ & $\begin{array}{l}\text { Horizontal } \\
\text { crack-like } \\
\text { indication }\end{array}$ & $\sim 60 \%$ TW & $5.8^{\prime \prime}$ & $\mathrm{N} / \mathrm{A}$ \\
\hline $\begin{array}{l}175^{\prime} \\
\text { UT data }\end{array}$ & $49 "$ & $\begin{array}{l}\text { Lower } \\
\text { plate } \\
\text { vertical } \\
\text { weld } \\
\end{array}$ & $\begin{array}{l}\text { Horizontal } \\
\text { crack-like } \\
\text { indication }\end{array}$ & $\sim 60 \%$ TW & $1.4 "$ & N/A \\
\hline $\begin{array}{l}181^{\prime} \\
\text { UT data }\end{array}$ & $31 "$ & $\begin{array}{l}\text { Just above } \\
\text { Bottom } \\
\text { knuckle } \\
\text { weld }\end{array}$ & $\begin{array}{l}\text { Vertical crack- } \\
\text { like indication }\end{array}$ & $\sim 20 \%$ TW & $\mathrm{N} / \mathrm{A}$ & $0.55^{\prime \prime}$ \\
\hline $\begin{array}{l}192^{\prime} \\
\text { UT and VT }\end{array}$ & $150 "$ & $\begin{array}{l}\text { Middle } \\
\text { horizontal } \\
\text { weld }\end{array}$ & $\begin{array}{l}\text { Arched } \\
\text { horizontal } \\
\text { crack }\end{array}$ & $\begin{array}{l}\text { Leak Site } \\
100 \% \\
\text { through-wall } \\
\text { (TW) } \\
\end{array}$ & $\begin{array}{l}10.2 " \mathrm{TW} \\
18.1 " \text { total }\end{array}$ & 3" arch \\
\hline $\begin{array}{l}201 \\
\text { VT }\end{array}$ & $30 "$ & 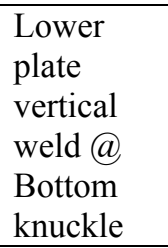 & $\begin{array}{l}\text { Leak site } \\
\text { Visual only }\end{array}$ & Leak site & $\mathrm{N} / \mathrm{A}$ & $\mathrm{N} / \mathrm{A}$ \\
\hline $\begin{array}{l}207^{\circ} \\
\text { UT and VT }\end{array}$ & $150 "$ & $\begin{array}{l}\text { Middle } \\
\text { horizontal } \\
\text { weld }\end{array}$ & $\begin{array}{l}\text { Arched } \\
\text { horizontal } \\
\text { crack }\end{array}$ & $\begin{array}{l}\text { Leak Site } \\
100 \% \\
\text { through-wall } \\
\text { (TW) }\end{array}$ & $\begin{array}{l}12.7 " \mathrm{TW}, \\
17.5 " \text { total }\end{array}$ & $8 "$ \\
\hline
\end{tabular}




\subsubsection{Thickness Mapping}

Thickness mapping was performed on $1 \%$ of the circumference of the tank for the entire accessible height of the tank (see Figure 9 and Table 2). These thickness mapping examinations were performed to detect and measure any general wall loss, pitting or interface attack in all regions of the tank including the vapor space. No reportable wall loss or pitting was detected.

Figure 9: Average Thickness Summary Plot

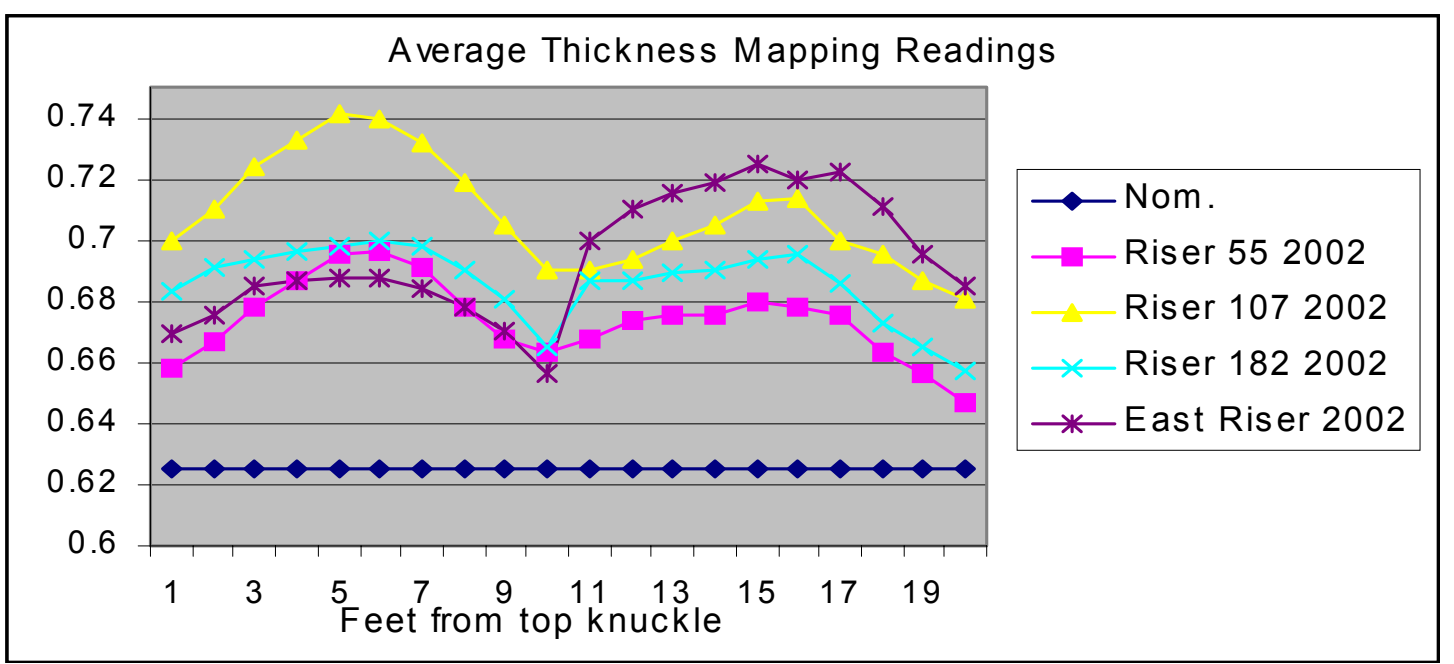

TABle 2: THICKNESS MAPPING AVERAGE THICKNESS SUMMARY

\begin{tabular}{|c|c|c|c|c|c|}
\hline Feet Down & Nom. & Riser IP 55 2002 & Riser IP 107 2002 & Riser IP 182 2002 & East Riser 2002 \\
\hline 1 & 0.625 & 0.658 & 0.7 & 0.683 & 0.669 \\
\hline 2 & 0.625 & 0.667 & 0.71 & 0.691 & 0.675 \\
\hline 3 & 0.625 & 0.678 & 0.724 & 0.694 & 0.685 \\
\hline 4 & 0.625 & 0.687 & 0.733 & 0.696 & 0.687 \\
\hline 5 & 0.625 & 0.695 & 0.741 & 0.698 & 0.688 \\
\hline 6 & 0.625 & 0.696 & 0.74 & 0.700 & 0.688 \\
\hline 7 & 0.625 & 0.691 & 0.732 & 0.698 & 0.684 \\
\hline 8 & 0.625 & 0.678 & 0.719 & 0.690 & 0.678 \\
\hline 9 & 0.625 & 0.668 & 0.705 & 0.681 & 0.670 \\
\hline 10 & 0.625 & 0.663 & 0.69 & 0.665 & 0.656 \\
\hline 11 & 0.625 & 0.668 & 0.69 & 0.687 & 0.700 \\
\hline 12 & 0.625 & 0.674 & 0.694 & 0.687 & 0.710 \\
\hline 13 & 0.625 & 0.675 & 0.7 & 0.689 & 0.715 \\
\hline 14 & 0.625 & 0.675 & 0.705 & 0.690 & 0.719 \\
\hline 15 & 0.625 & 0.68 & 0.713 & 0.694 & 0.725 \\
\hline 16 & 0.625 & 0.678 & 0.714 & 0.695 & 0.720 \\
\hline 17 & 0.625 & 0.675 & 0.7 & 0.686 & 0.722 \\
\hline 18 & 0.625 & 0.663 & 0.695 & 0.673 & 0.711 \\
\hline 19 & 0.625 & 0.656 & 0.687 & 0.665 & 0.695 \\
\hline 20 & 0.625 & 0.647 & 0.681 & 0.657 & 0.685 \\
\hline
\end{tabular}




\subsection{Historical Thickness Data Comparison}

An ultrasonic thickness measurement program was implemented for HLW tanks in 1972. This program continued until 1984 when it was discontinued because no indications of service induced, general corrosion were detected. The historical UT spot readings were aimed at detecting and measuring wall loss from general corrosion. A different ultrasonic technique was used to make the spot readings than was used for the thickness mapping that is now done. Although both are ultrasonic thickness measurements, they had different purposes, therefore the readings are not suited for direct correlation without a technical understanding of the differences and tolerances involved with each.

The historical, spot reading data was collected with a multiple echo technique which provides a precise measurement of steel thickness while minimizing the error from any coating or changes in contact from surface debris. The recent thickness mapping was focused on detecting pitting and other corrosion related wall loss and therefore a dual element transducer was utilized. The multiple echo technique was not used since the tank was not painted and multiple echo is not as sensitive to pitting. The tank surface had a light surface corrosion and debris from $\sim 42$ years of service. This surface debris likely induced some error into the recent thickness mapping readings.

Comparison is further complicated by the disparity in the number of data points being compared. The historical spot reading data included a generous amount of single spot readings. Readings were taken at two to six inch intervals for the entire accessible height resulting in approximately 50 readings in one vertical strip. The thickness mapping data includes thickness measurements at 0.050 inch intervals over the entire 8.5 inch wide strip for the entire accessible height. This resulted in well over 720,000 readings in each of the 4 vertical strips.

Figure 10 shows a graph of the results of the historical thickness readings from Tank 15. Thickness spot readings were taken in the South riser of Tank 15 in 1972, 1977, 1980 and 1984. The readings show that there was no accelerated, general wall loss. The graph displays spot thickness data over a 12 year time period representing from 12 to 24 years in service.

The graph shows data from the two upper and lower primary shell plates between the top and bottom knuckles. This is the same area that was examined by thickness mapping in 2002. The historical spot reading data shows the typical pattern for waste tank plates where the edges of the rolled plates are thinner. The data from a given tank elevation from all successive readings are well within the 0.011 inch tolerance or uncertainty value. ${ }^{\text {vii }}$

\section{Figure 10: Historical UT Spot Readings - South Riser}

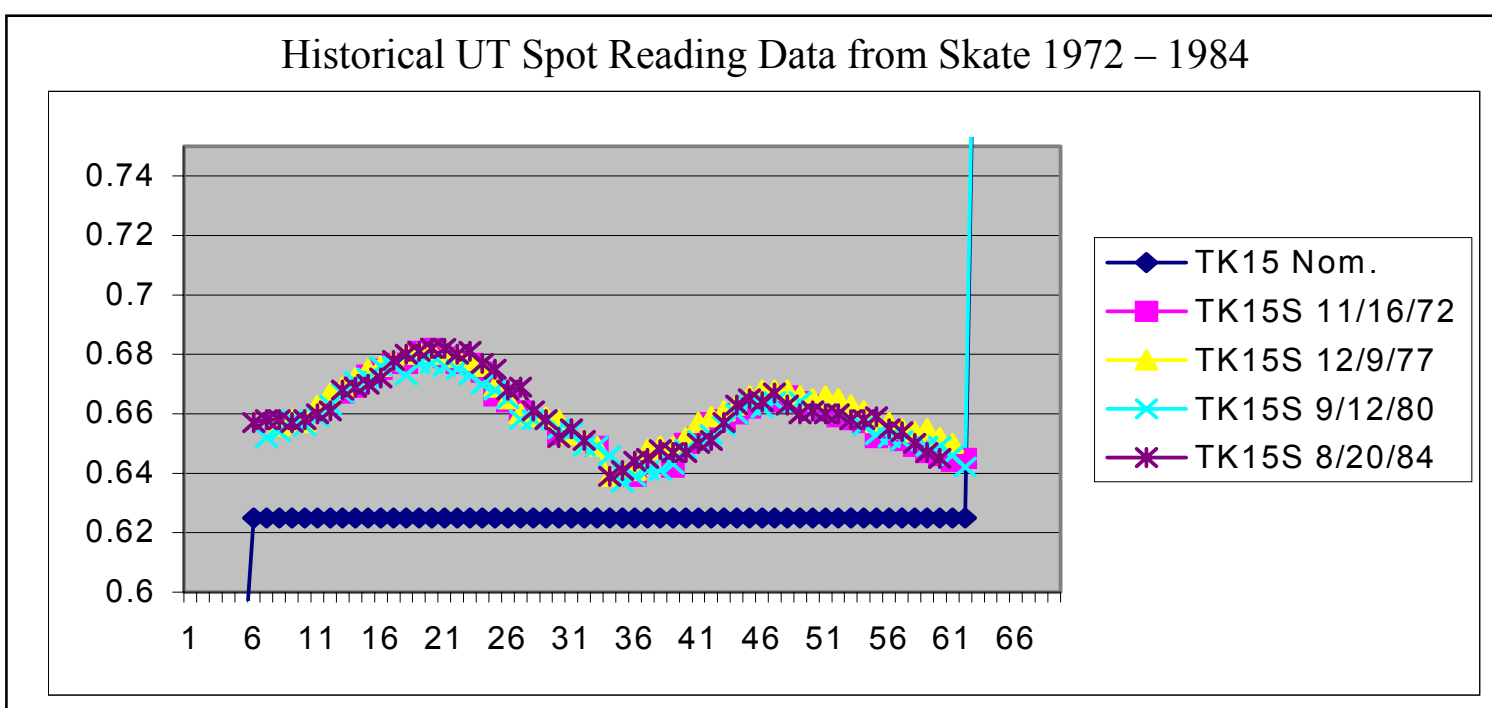

Thickness in inches (y axis) vs. readings from the top knuckle to shell weld (x axis). 
With the understanding that direct comparison is not intended, the following "Apples and Oranges" plots are provided to give an example of tank wall thickness over time (see Figures 11 and 12). Note that each set of data is from a separate riser and are therefore from separate plates of steel. Variations in thickness from one plate to the next (vertically and horizontally) are typical in tank construction. The 2002 average thickness data is typically reported to be thicker than the 1972 data. This is due to variations in the UT technique summarized earlier in this section. The pertinent information is that the typical thickness pattern remains unchanged which indicates that there is no accelerated general wall loss at any elevation in the tank.

Figure 11: Average Thickness Mapping Data vs Initial Spot Reading Data

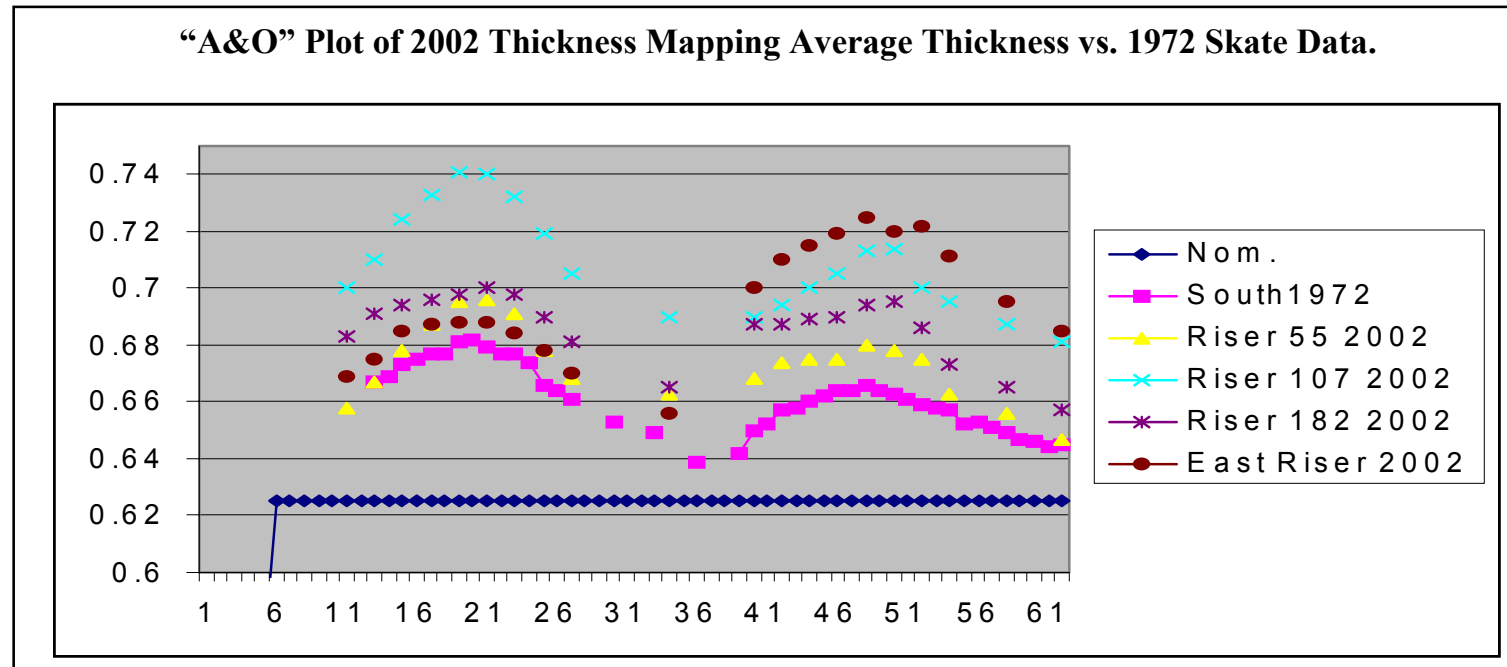

Thickness in inches (y axis) vs. readings from the top knuckle to shell weld (x axis).

In the following figure the minimum thicknesses from the 2002 thickness mapping examinations are plotted along with the 1972 Spot UT thickness data. Again, the same typical, tank plate thickness profile is evident. Only 1 small area was detected with a minimum thickness below nominal thickness.

Figure 12: Minimum Thickness Mapping Data vs Initial Spot Reading Data

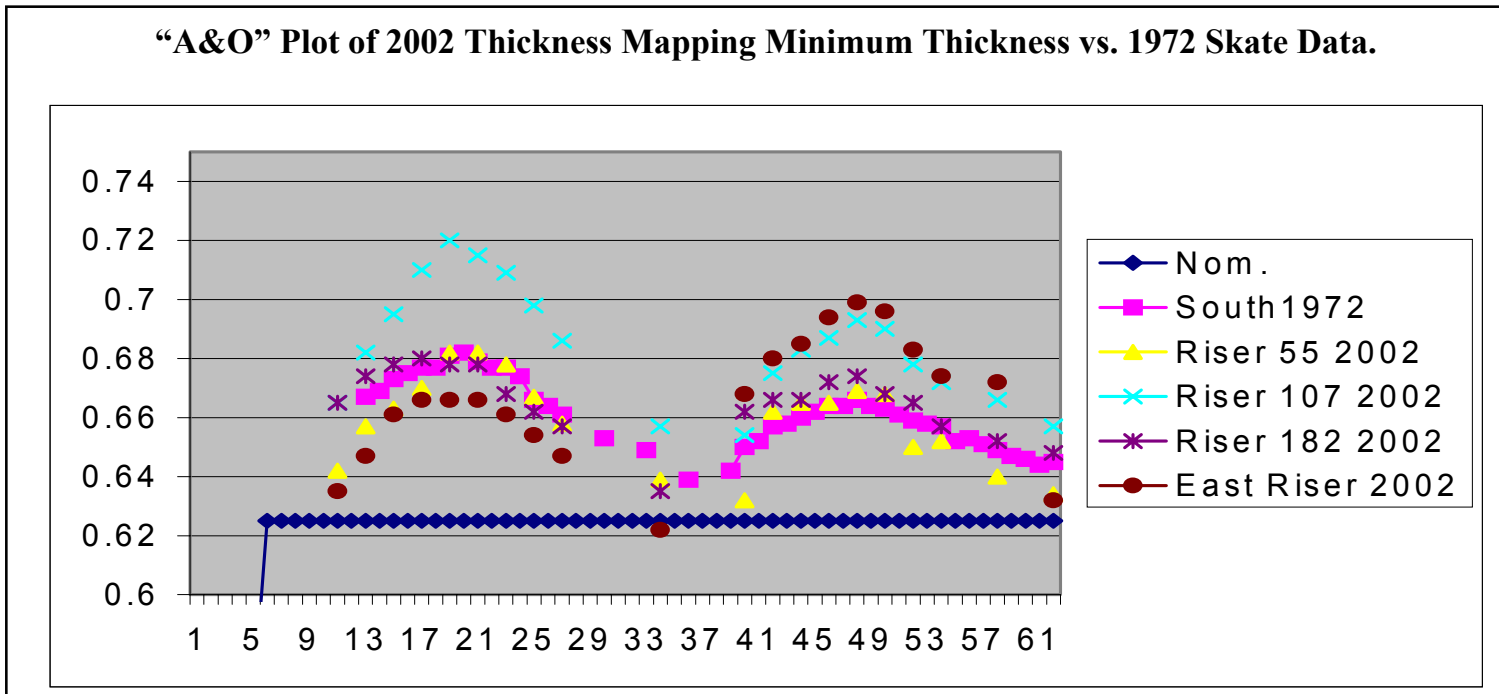

Thickness in inches (y axis) vs. readings from the top knuckle to shell weld (x axis). 


\subsection{Riser IP 55 Results}

\subsubsection{Vertical Strip}

Inspections of Tank 15 through riser IP 55 included one vertical strip for the entire accessible height of the tank. No reportable areas were detected in the vertical strip. The minimum thickness detected in the upper and lower plates are above nominal thickness. The minimum thickness detected in the upper plate was 0.639 inch and is near the edge of the plate toward the middle weld. The minimum thickness detected in the lower plate was 0.632 inch. This minimum thickness area is a $0.25 \times 0.40 \times 0.030$ inch deep indication approximately 2.5 inches from the middle weld. The minimum thickness at the bottom of the same plate is 0.634 inch. The indication is in the black circle (see Figure 13). The image shows the plate to be thinner at the edges. There are several noise spikes shown in the side and end views. These noise indications were evaluated and determined to be non-relevant. No Crack-like indications were detected in this strip.

Figure 13: Thickness Mapping Image of Lower Plate, Riser 55

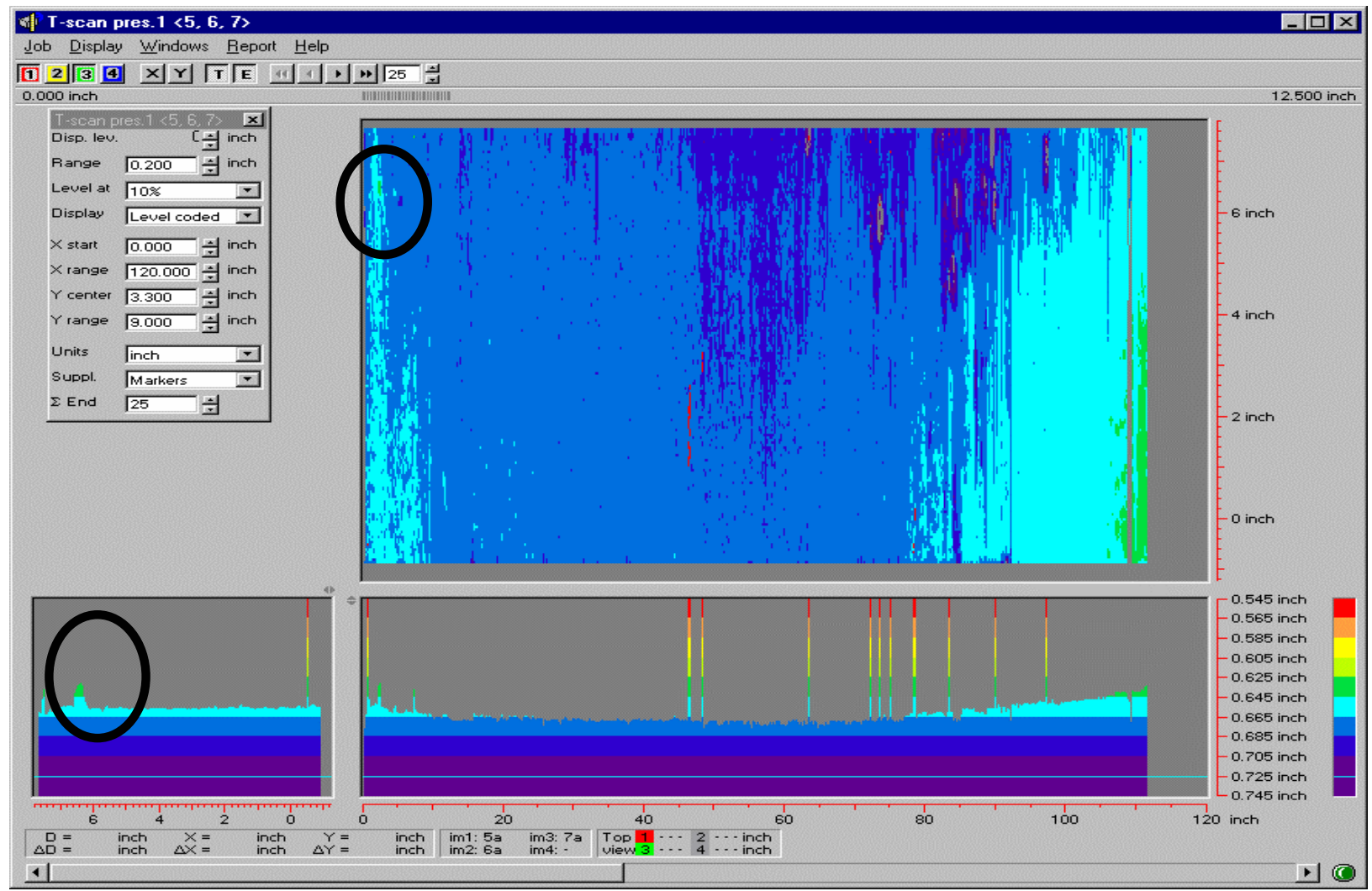




\subsubsection{Previous Indication Investigation}

One previously identified indication in the upper plate vertical weld at approximately 53 feet was also examined under riser IP55. The indication was observed at 200 inches above the tank bottom. Due to the high weld profile and limited time and the fact that the examination of this leaksite was not a requirement of the Tank 15 ISI scope, the indication was only examined from one side of the vertical weld. The examinations were performed on the side of the weld opposite the riser. The crack was confirmed to be through wall, but also had a partial through wall segment. Measuring the indication on the right side only, the through wall portion was 1.4 inches. The total length was 3.7 inches on that side of the weld. Figure 15 shows some of the UT data from this indication.

\section{Figure 14: Visual Image of Crack in Upper Plate Vertical Weld, Riser 55}

A picture of the indication at 200 inches above the tank bottom, rotated to the same orientation as the P-scan data is shown in Figure 13. The image is rotated 180 degrees (up-side down). The vertical weld edges are marked on the image. Only the part of the indication on the left side of the picture was scanned (Right side of weld looking at tank). The through wall portion of that crack which is visible in the picture is represented by the blue portion of the P-scan data in Figure 14. The yellow and green portions of the Pscan image indicate the part of the crack that is only partially through wall.

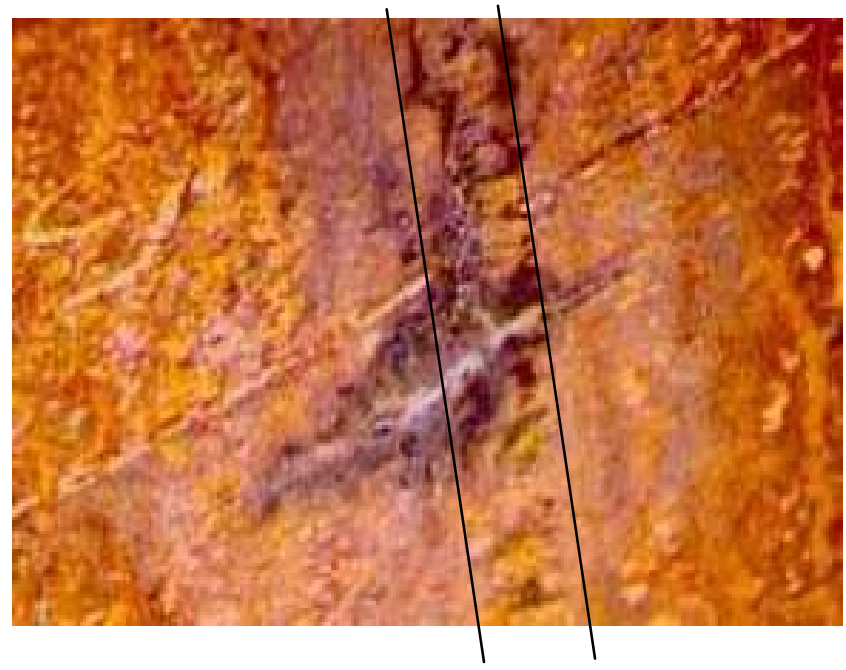

Figure 15: P-scan Data of Crack in Upper Plate Vertical Weld, Riser 55

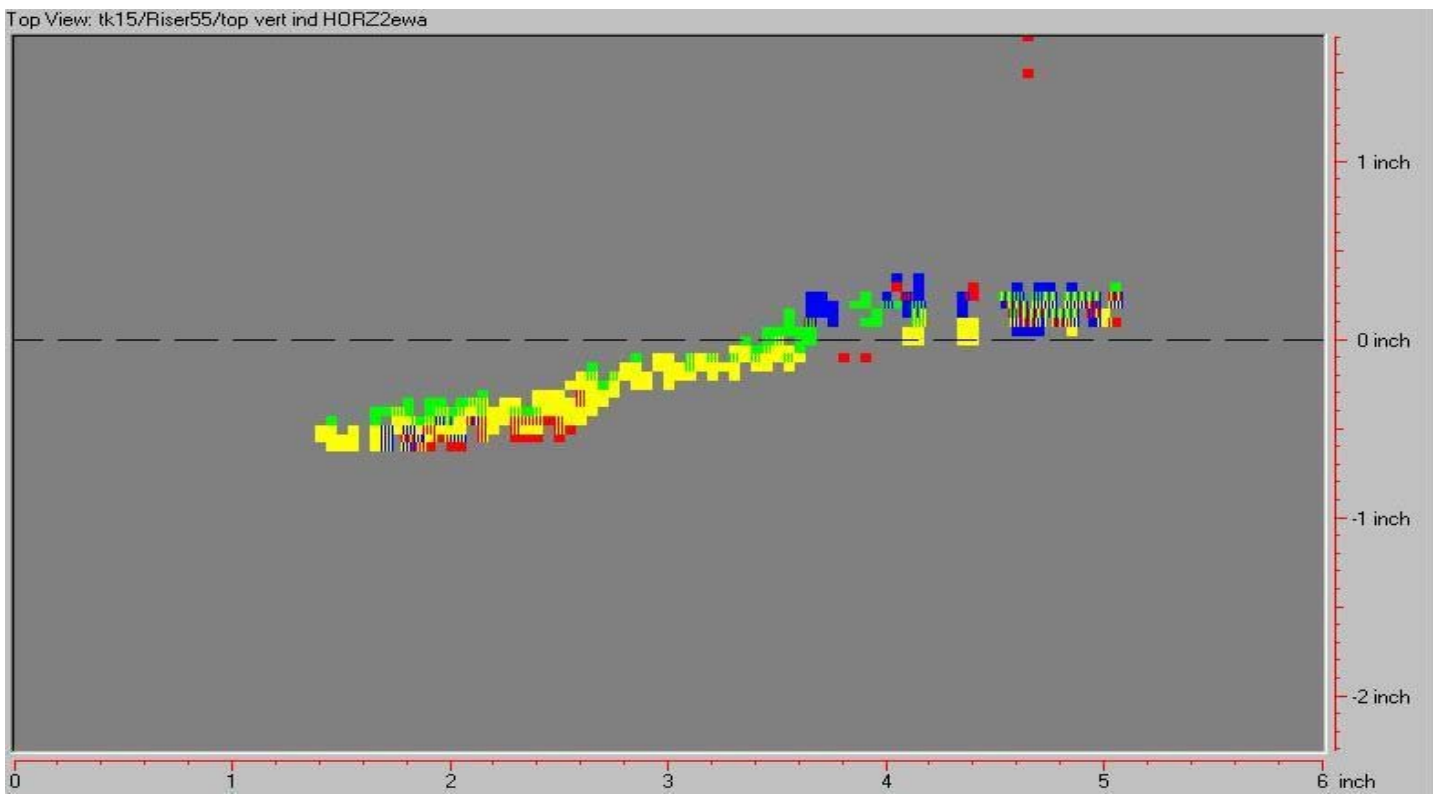




\subsection{Riser IP 107 Results}

\subsubsection{Vertical Strip}

Inspections of Tank 15 through riser IP 107 included one vertical strip for the entire accessible height of the tank. No reportable areas were detected in the vertical strip. The minimum thickness detected in the upper and lower plates are above nominal thickness. The minimum thickness detected in the upper plate was $0.657 \mathrm{in}$. and is near the edge of the plate at the middle horizontal weld. An area was recorded with a minimum thickness of 0.665 in. and is a $0.23 \times 0.538 \times 0.035$ inch deep indication near the top weld. The minimum thickness detected in the lower plate was 0.654 in. and is near the middle horizontal weld Figure 16 shows the vertical strip scan of the lower shell plate The image shows the plate to be thinner at the edges. There were rough surface areas causing loss of data and several noise spikes. These noise indications were evaluated and determined to be non-relevant. No crack-like indications were detected.

Figure 16: Thickness Mapping Image of Lower Plate, Riser 107

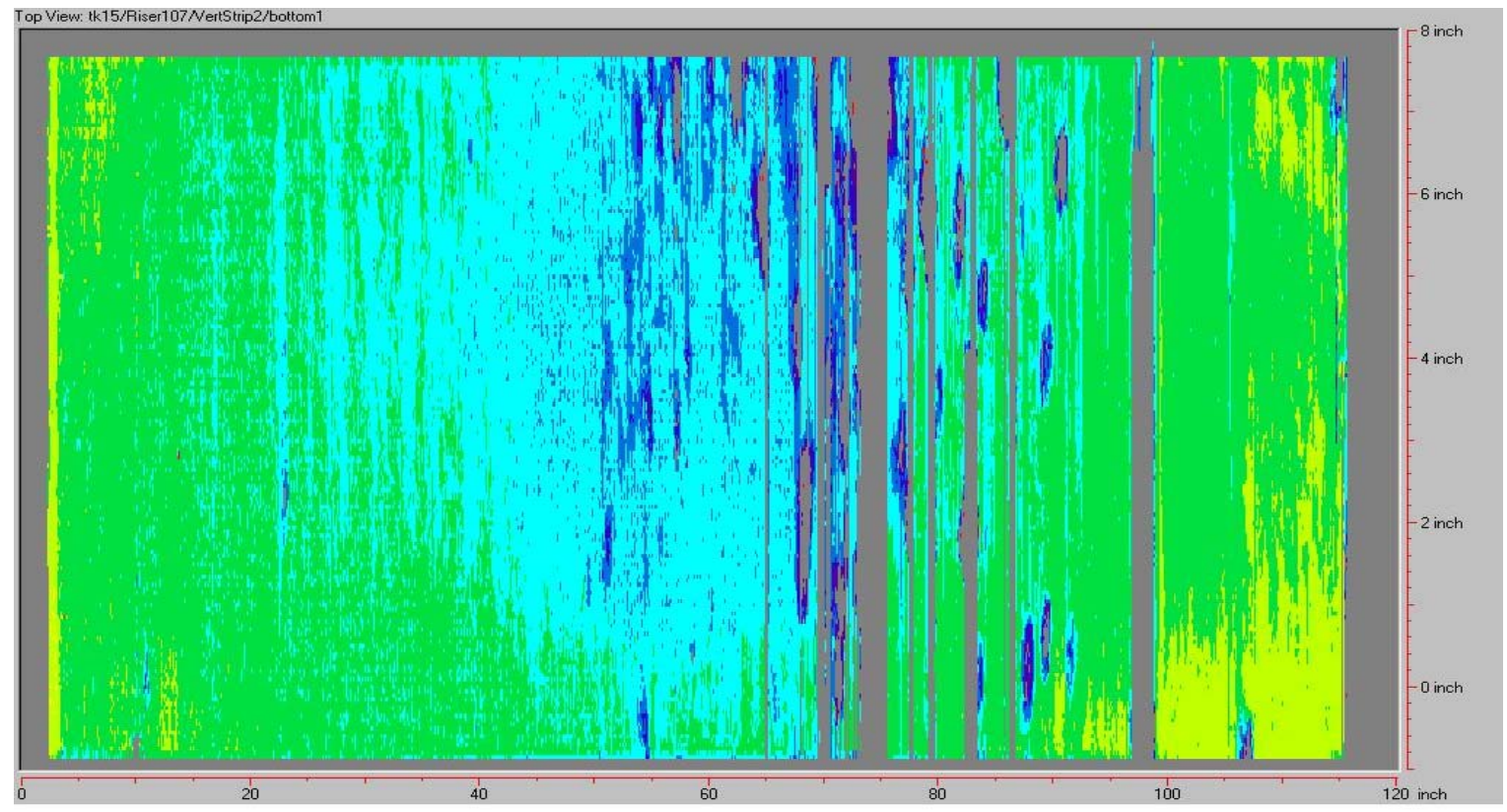




\subsubsection{Previous Indication}

One previously identified leak site at 115 feet and 88 inches above the tank bottom, in the middle of the lower plate was also examined. (Determined to be attachment weld)

This indication was scanned several times. The indication is in the shape of an arch. Due to the attachment weld on the exterior of the tank, one end of the indication could not be scanned. The length of the accessible area was measured to be 3.7 inches ( 3.7 inches vertically, 2.3 inches horizontally).

Figure 17: Picture of Mid Plate Indication at Attachment, Riser 107

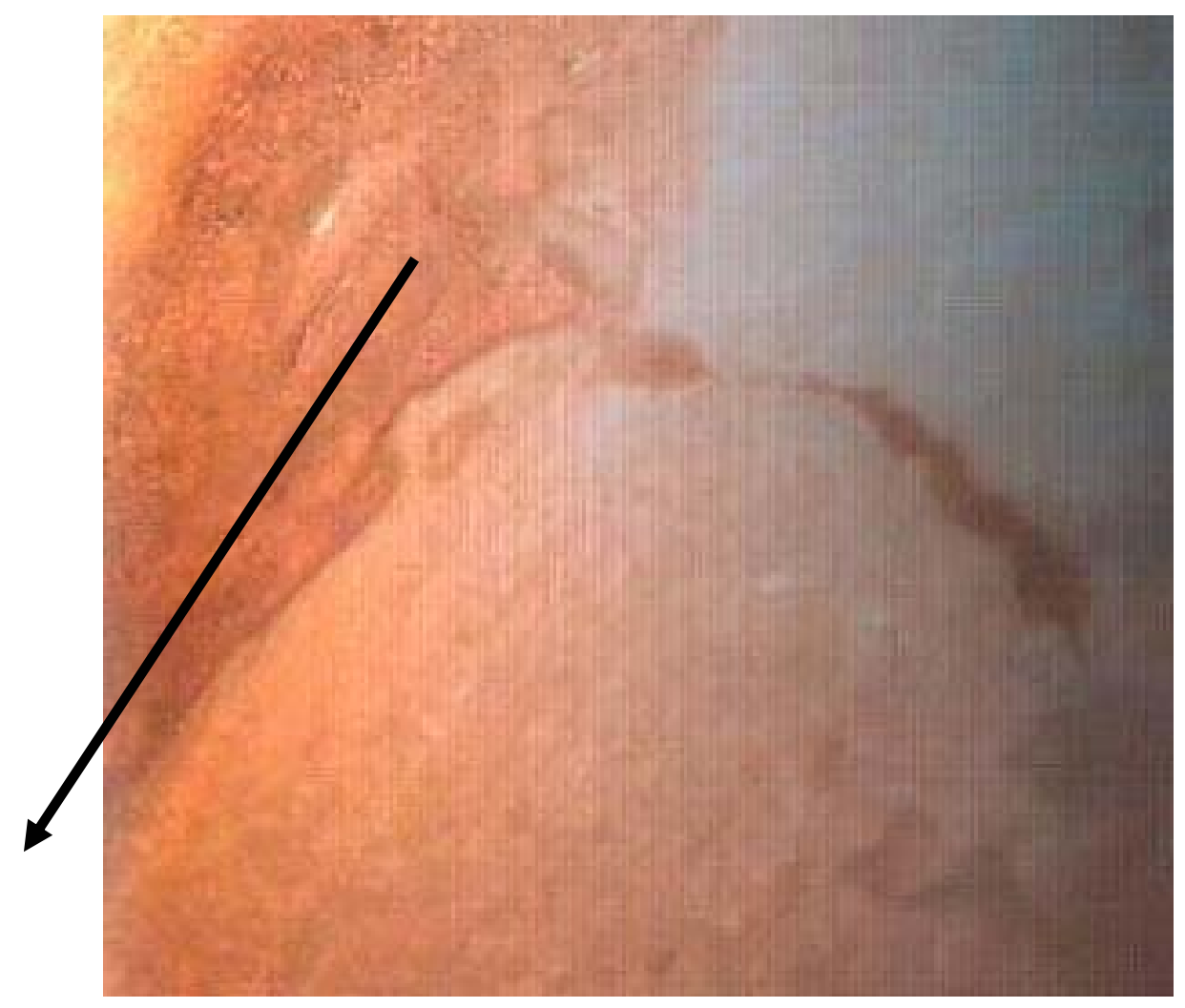

Figure 17 shows part of the arch shaped indication. The image is actually rotated about 15 degrees. The arrow is in the area where it appears that the lifting lug was knocked off. (arrow points toward bottom of tank). Based on the UT and bleed-out, the indication appears to continue into the attachment removal area. 


\subsection{East Riser (IP 197 via IP 182) Results}

\subsubsection{Vertical Strip}

Inspections of Tank 15 under the East riser were performed through riser IP182 and consisted of one vertical strip for the entire accessible height of the tank. One of these two strips is summarized under the East riser inspections. In the vertical strip performed under the East riser there were no reportable thickness areas detected. The minimum thickness detected in the upper plate was $0.622 \mathrm{in}$. (only 0.003 in. less than nominal thickness) and was located near the middle weld. One area near the top knuckle weld was noted as a $0.34 \times 0.97 \times 0.040$ inch deep indication. The minimum thickness detected in the lower plate was $0.632 \mathrm{in}$. and is in the weld preparation area, near the bottom knuckle weld No cracklike indications were detected in the vertical strip.

Figure 18: Thickness Map of the Lower Plate Vertical Strip, East Riser

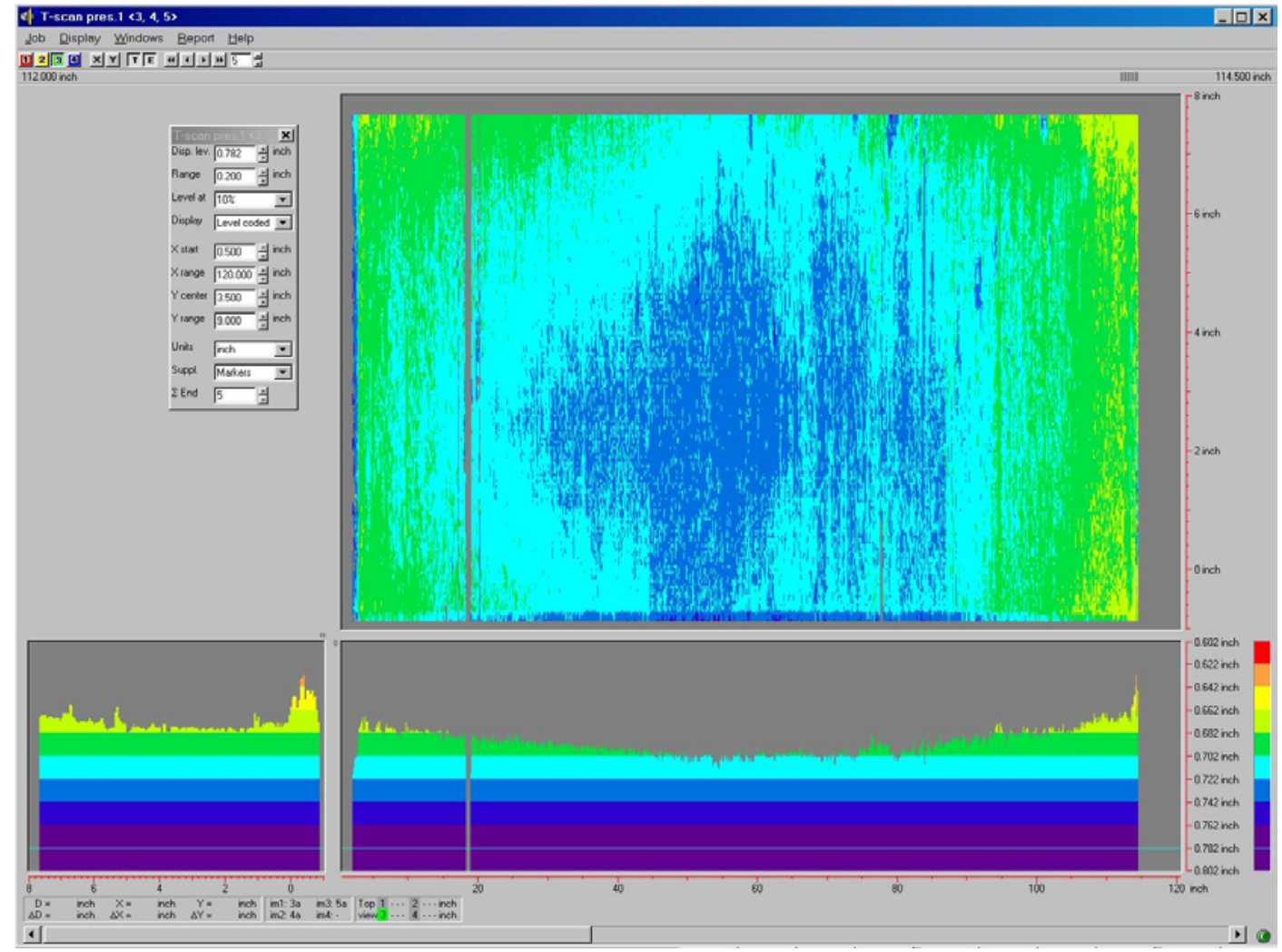




\subsection{Riser IP 182 Results}

\subsubsection{Vertical Strip}

Inspections of Tank 15 through riser IP182 included two vertical strips for the entire accessible height of the tank. One of these two strips is summarized under the East riser inspections. In the vertical strip performed under riser IP 182 there were no reportable thickness areas detected. One new, partial through wall crack indication was detected at the bottom of the vertical strip, near the bottom knuckle. The indication was determined to be 0.55 inch long and approximately $20 \%$ through wall. The partial through wall ID indication is approximately one inch from the toe of the bottom knuckle weld.

The minimum thicknesses detected in the upper and lower plates was above nominal thickness. The minimum thickness detected in the upper plate was 0.635 inch and is near the edge of the plate toward the middle weld. This minimum thickness area is a $0.23 \times 0.389 \times 0.023$ inch deep indication near the middle horizontal weld. The minimum thickness detected in the lower plate was $0.648 \mathrm{in}$. and is near the bottom knuckle weld

\subsubsection{Lower Plate Vertical Weld}

The vertical weld in the lower plate located at 175 feet was examined for vertical and horizontal cracking. Due to the high weld crown geometry which prevented scanning in some areas, the entire length of weld could not be examined. Although the weld crown and multiple attachment welds prevented inspection of the majority of the weld, several sections of the weld were successfully examined. Four new crack indications were recorded on this weld. Figure 19 shows the weld at 175 feet and a large salt nodule covering a leak site on the vertical weld at 172 feet.

\section{Figure 19: Picture of Lower Plate Vertical Weld at 175 feet, Riser 182}

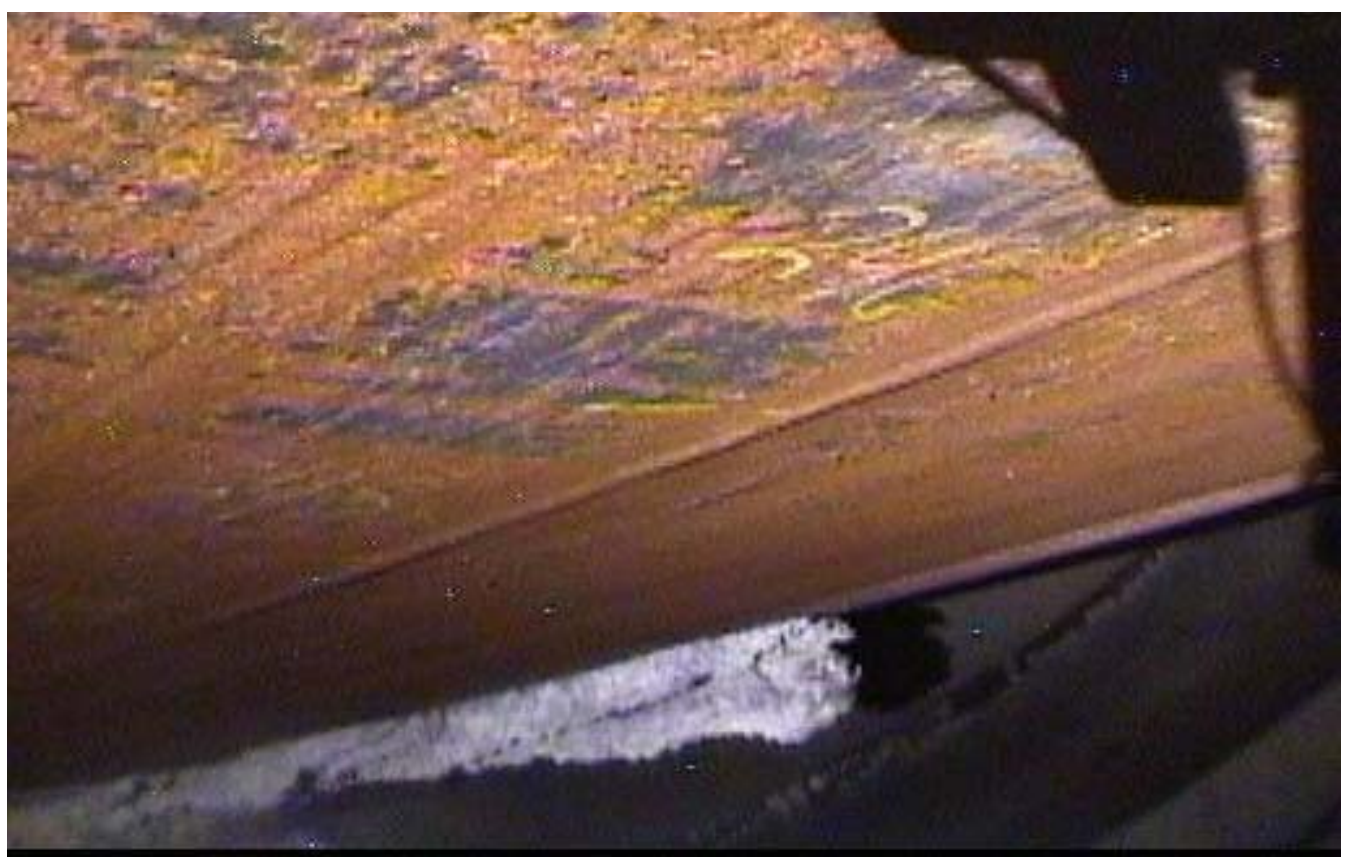


The following is a summary of the indications detected in the lower plate vertical weld at 175 feet. Four horizontal (perpendicular to the weld) indications were detected in the portions of the weld that were examined (see Table 1). The shortest indication was 1.2 inches and less than $25 \%$ through wall. The longest indication had a combined length (on both sides of weld) of 5.8 inches and was $60 \%$ through wall. The through wall indication (see Figure 20) measured 4.5 inches total length.

\section{Figure 20: P-scan Image of Horizontal Crack Across Vertical Weld at 175 feet}

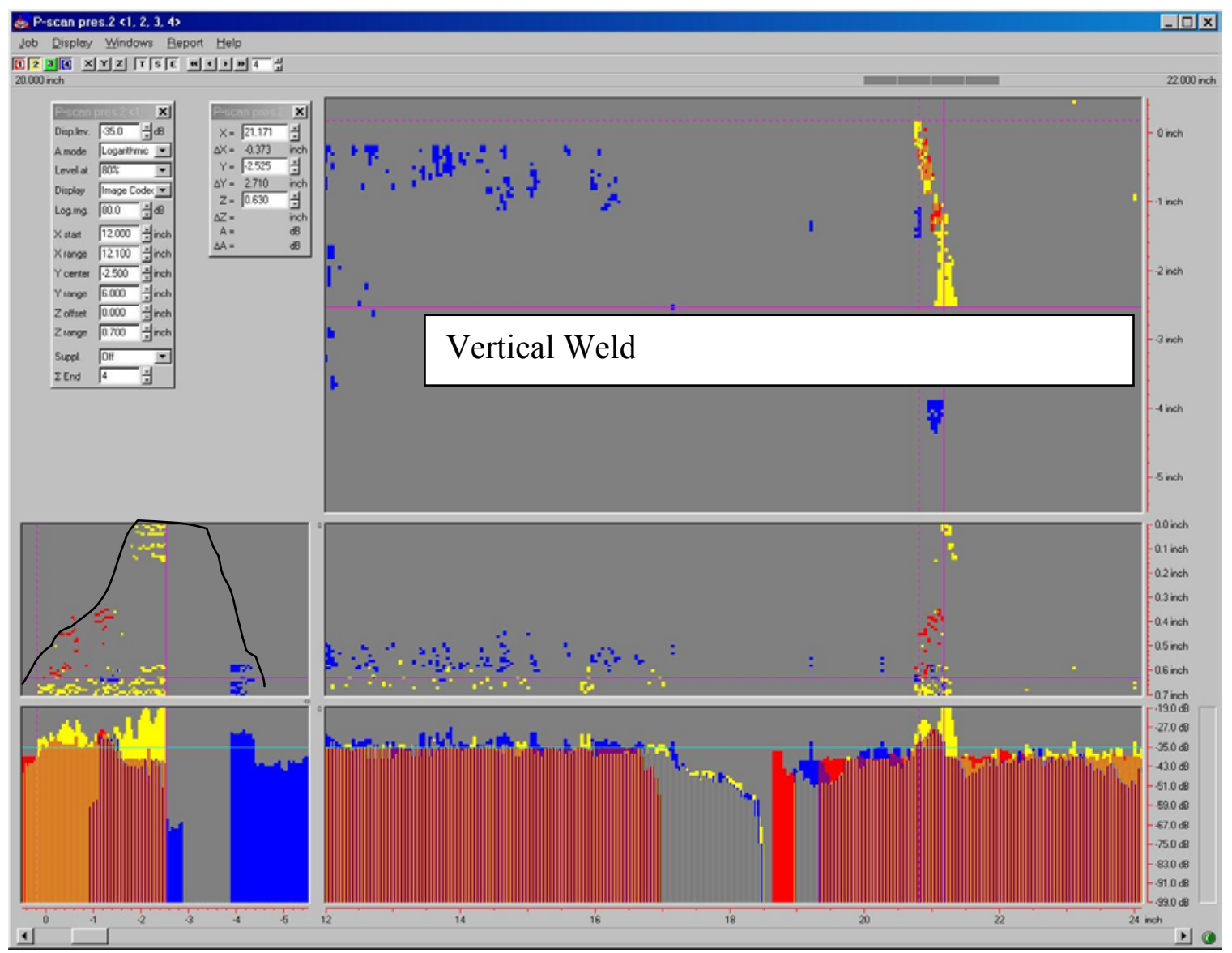

\subsubsection{Middle Horizontal Weld}

Middle Horizontal Weld - Approximately 33 feet of the middle horizontal weld was examined for horizontal and vertical cracking. The ISI Plan called for inspection of 15 feet of the middle horizontal weld and 15 feet of the upper weld of the bottom knuckle. Due to the geometry of the bottom knuckle weld and obstructions from the necklace alarm and support cable, the upper weld of the bottom knuckle could not be inspected. Inspection of an additional 15 feet of the middle horizontal weld was substituted for the inspection of the knuckle weld. The middle horizontal weld was examined in three sections, as noted:

- From 171 to 180 feet

- From 183 to 195 feet

- From 196 to 208 feet

- Three previously identified leak sites on the middle weld were also examined as follows: 


\subsubsection{Leak Site at 172 feet, Middle Horizontal Weld}

The leak site at 172 feet is a vertical crack perpendicular to the horizontal weld near a lower plate vertical weld. Figure 21 shows the thickness mapping scan in the area of the indication (upper plate only). Both of the P-scan images are rotated 90 degrees. Left to right on the image equates to starting above the horizontal weld and scanning down to the weld. The crack location in the upper plate is evident in the thickness mapping image due to loss of back-wall from the crack (gray horizontal line). The middle horizontal weld is at the right edge of the thickness mapping data.

Figure 21: Thickness Map of Crack at 172 feet Middle Horizontal Weld

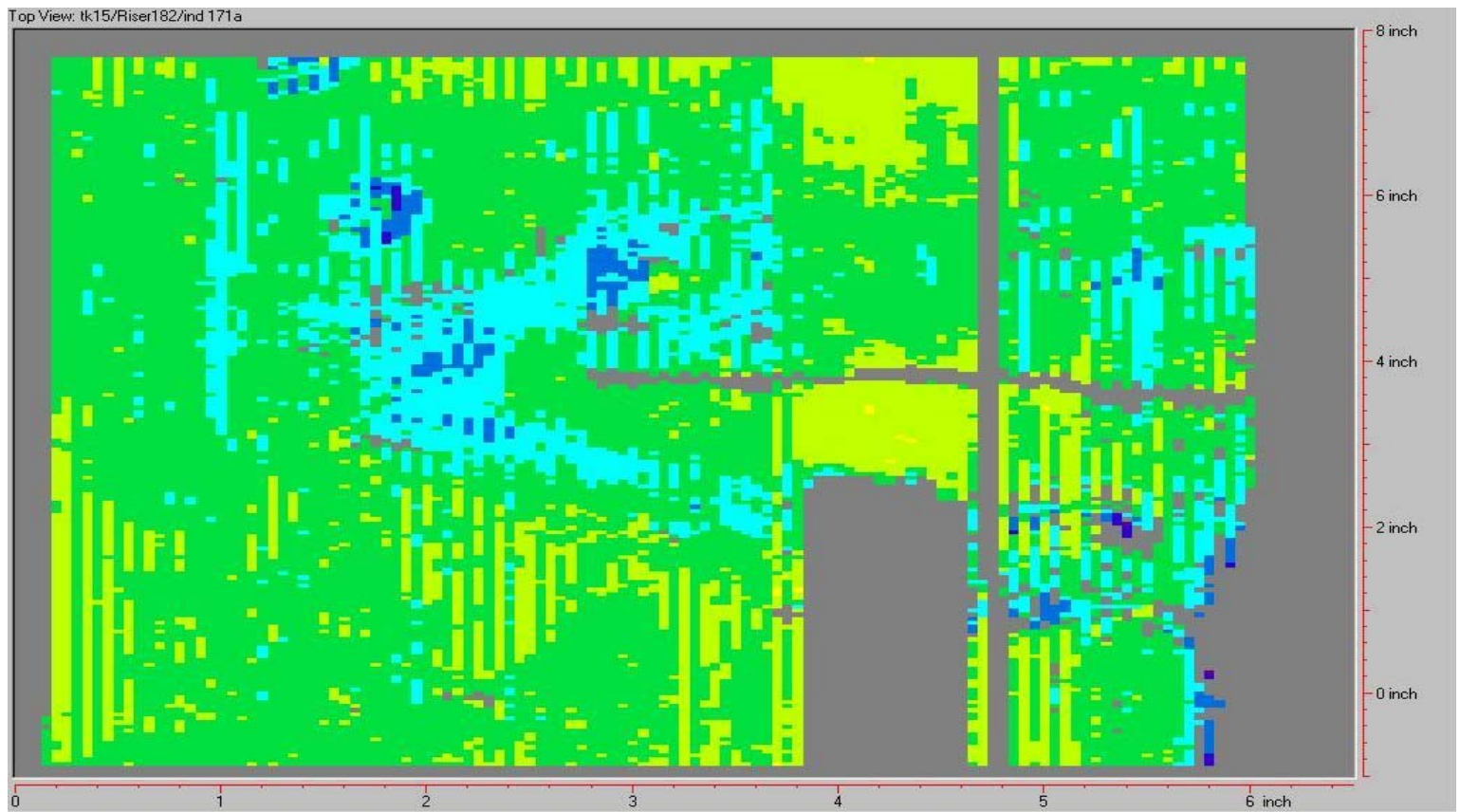

Figure 22: P-scan Image of Vertical Crack at 172 feet, Middle Horizontal Weld

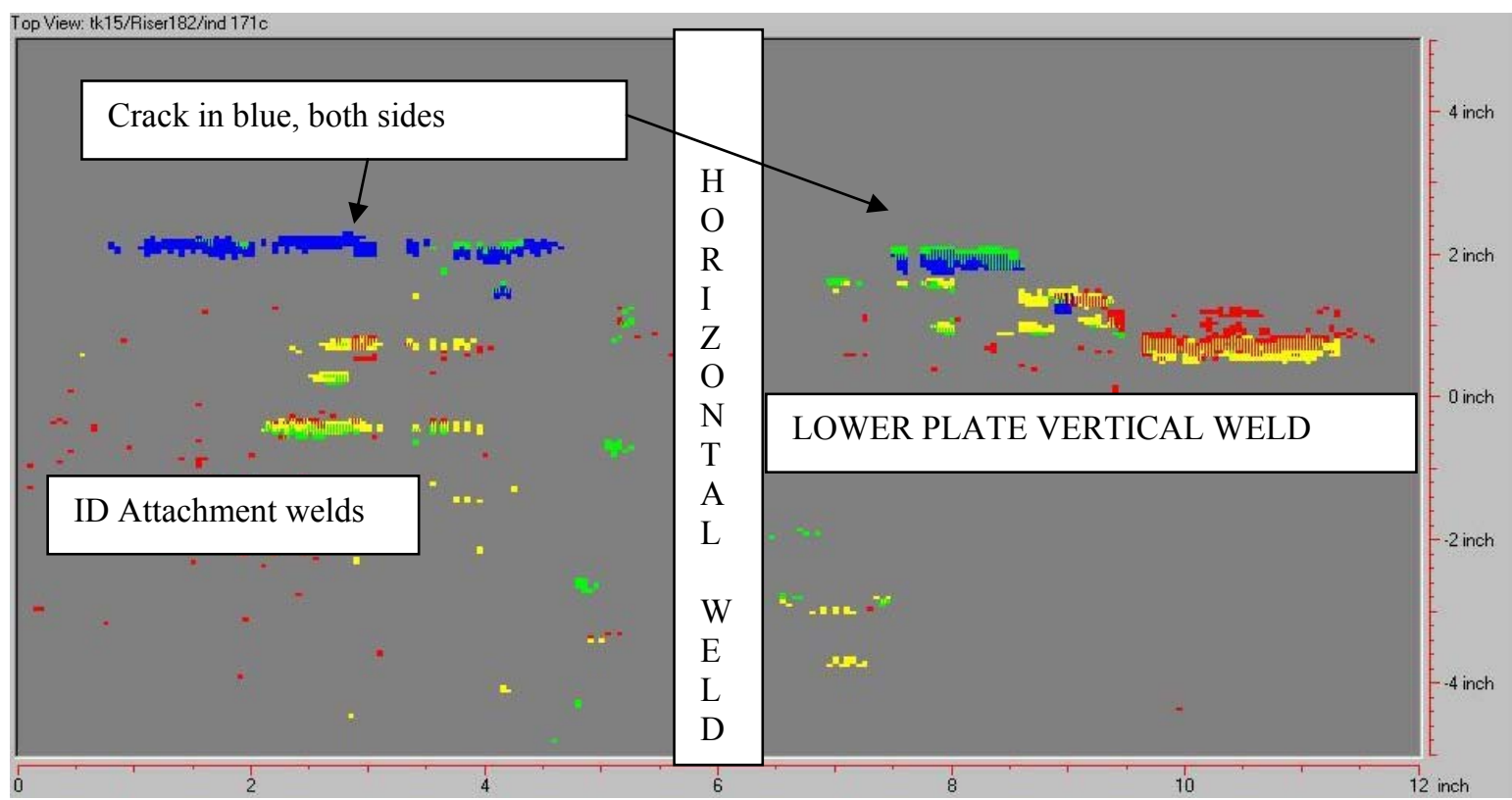




\subsubsection{Leak Site at 192 feet, Middle Horizontal Weld}

The leak site at 192 feet is a horizontal/arched crack in lower plate at a weld repair location. The throughwall portion (verified visually with bleed-out technique) of this crack was measured ultrasonically to be 10.2 inches. The indication is arch shaped around a significant weld repair in the horizontal weld. The weld repair area appears to be approximately 8 inches long and centered on the through-wall portion of the crack. The total length of the indication was measured at 18.1 inches. As shown in Figure 24, this indication is longer at the inside surface than on the outside. Figure 24 shows the end of the indication to be made up of multiple, shallow (partial through-wall) branches. This condition was also noted on the indication at 207 feet (Figure 28).

Figure 23: As-Found and Bleed-out Image of Crack at 192 feet, Middle Horizontal Weld
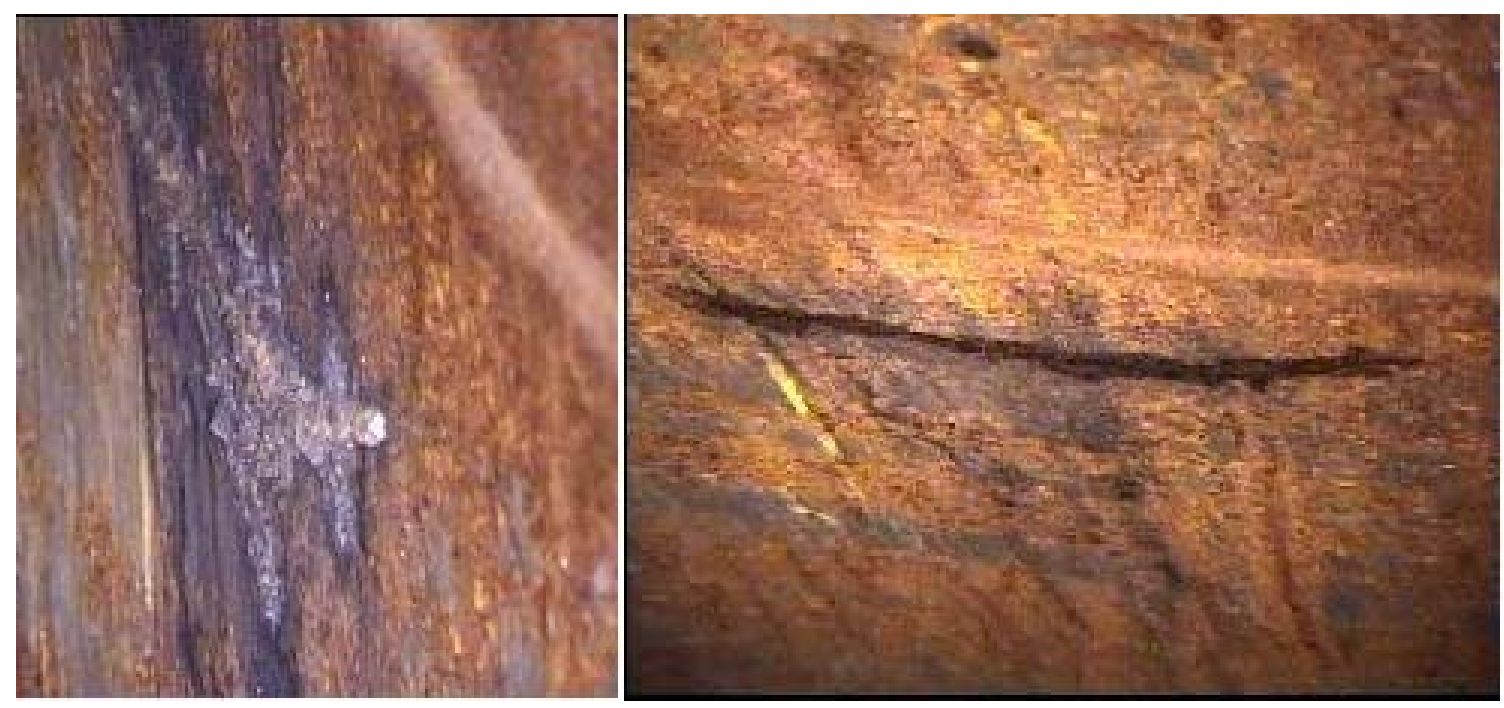

Figure 24: P-scan Image of Crack at 192 feet, Middle Horizontal Weld

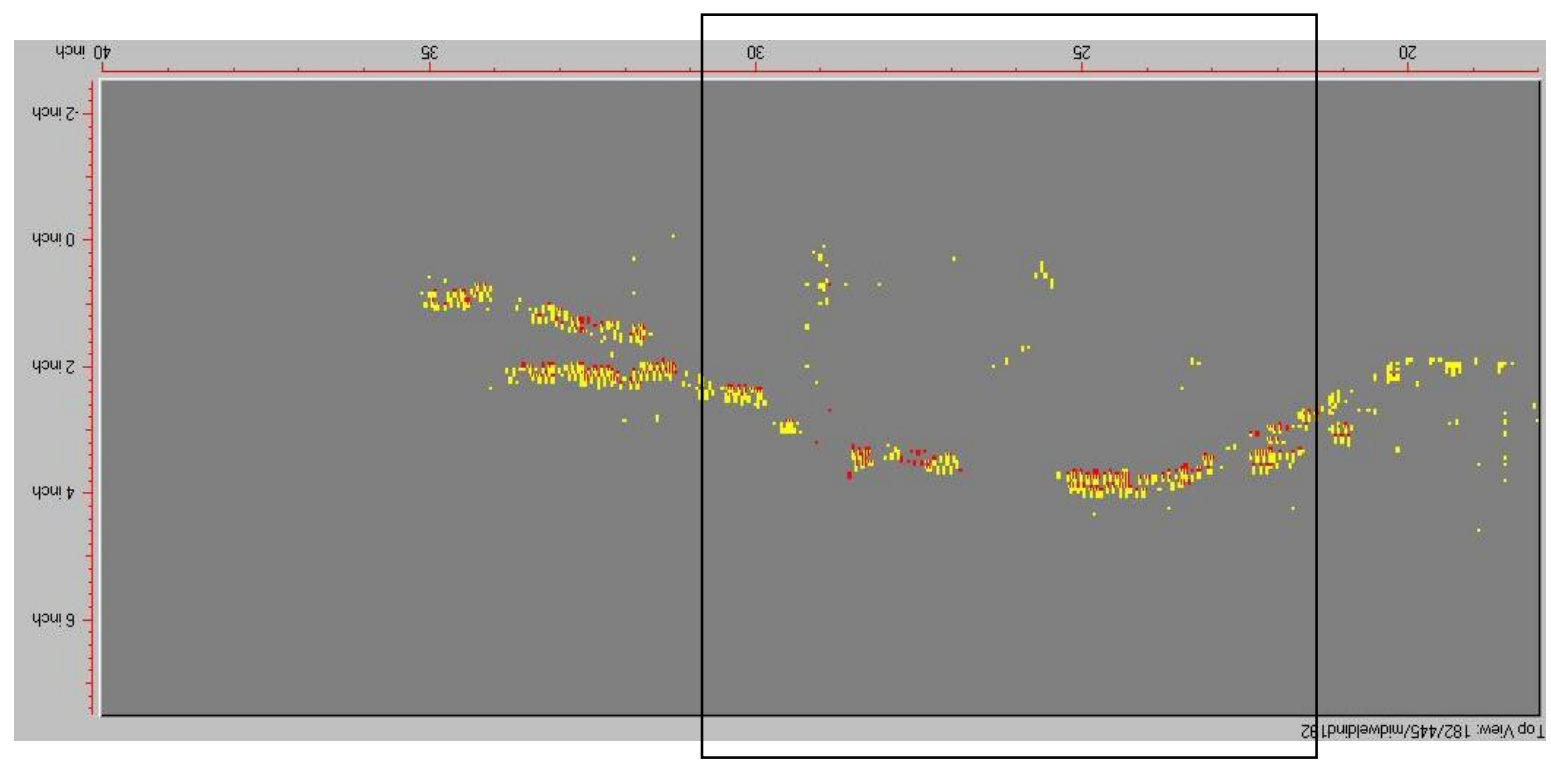

Through wall part of crack (shown in Figure 23) inside boxed area. P-scan image rotated to same orientation as visual image. 


\subsubsection{Leak Site at 207 feet, Middle Horizontal Weld}

Leak site at 207 feet is a horizontal/arched crack in lower plate at a weld repair location. The through-wall portion of this crack (verified visually with bleed-out technique, see Figure 27) was measured ultrasonically to be 12.7 inches. The indication is arch shaped around a significant weld repair in the horizontal weld. The total length of the indication was measured at 17.5 inches. Figure 25 show the indication in the "as-found" condition. As shown in Figure 28, this indication is longer at the inside surface than on the outside. Figure 28 also shows the end of the indication to be made up of multiple, shallow (partial through-wall) branches.

Figure 25: As-Found Image of Indication at 207 feet, Middle Horizontal Weld

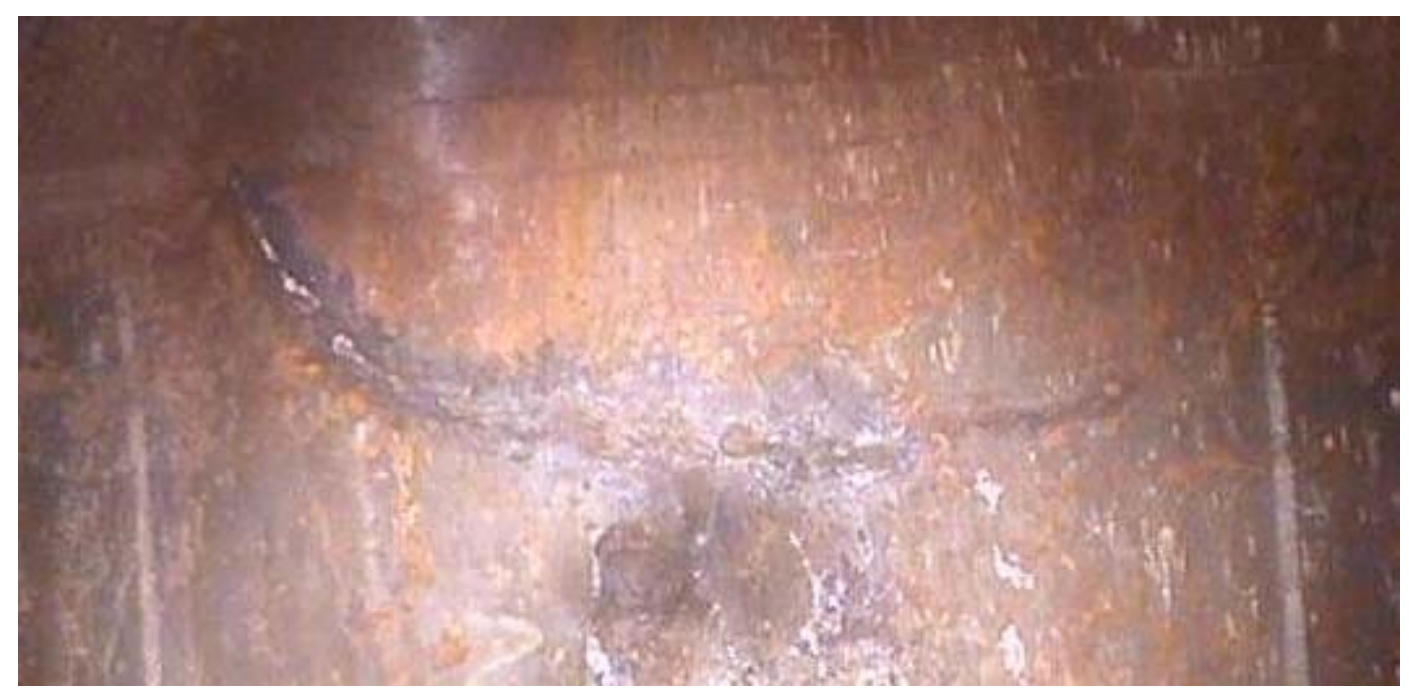

Figure 26: Image of Weld Repair at 207 feet Middle Weld

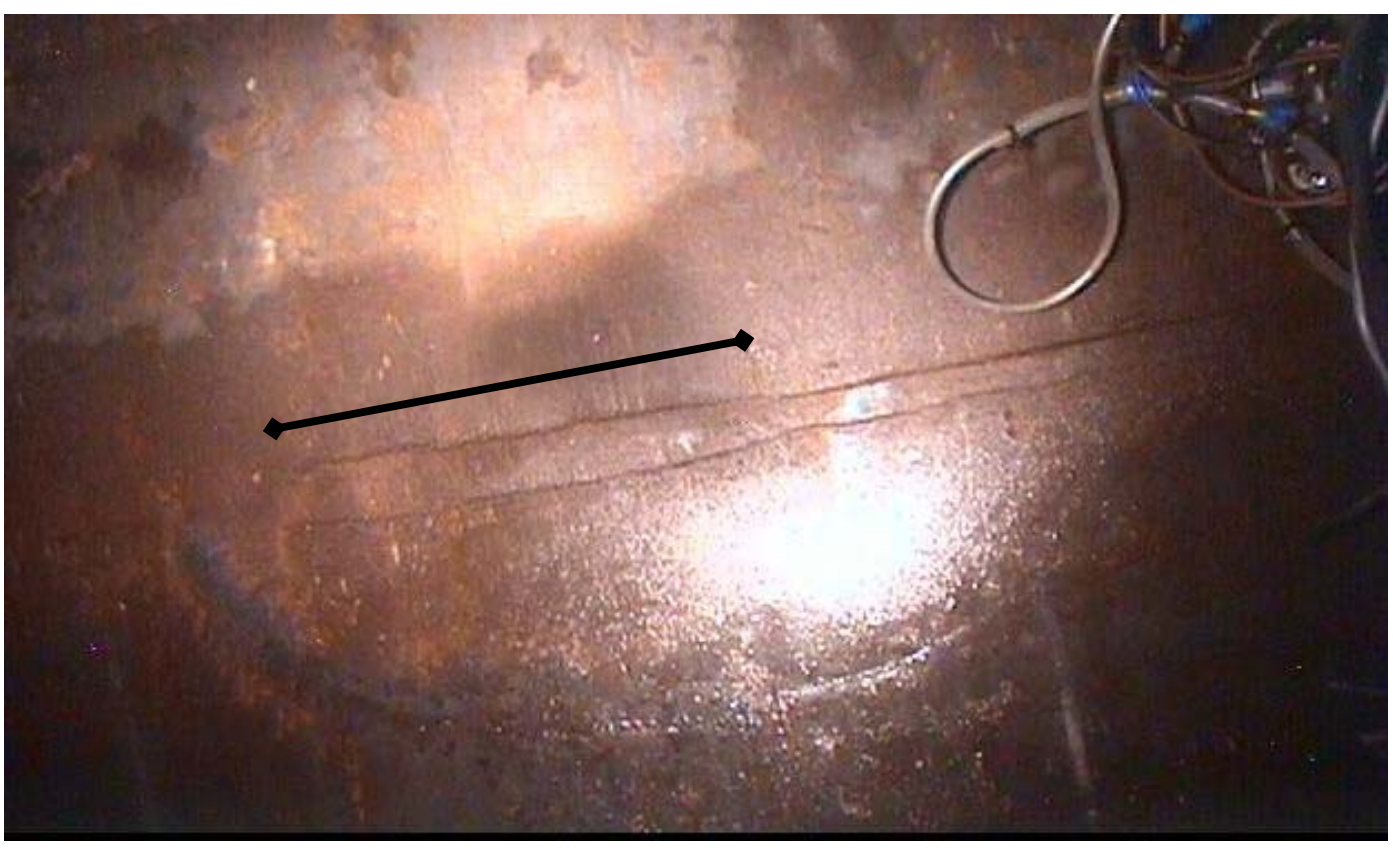

In the above image, the combination of the wet surface (water for UT couplant) and lighting provide a good view of the weld repair area. The repair area appears to be approximately 7 inches long. 
Figure 27: Image with Bleed-Out from Indication at 207 feet, Middle Horizontal Weld

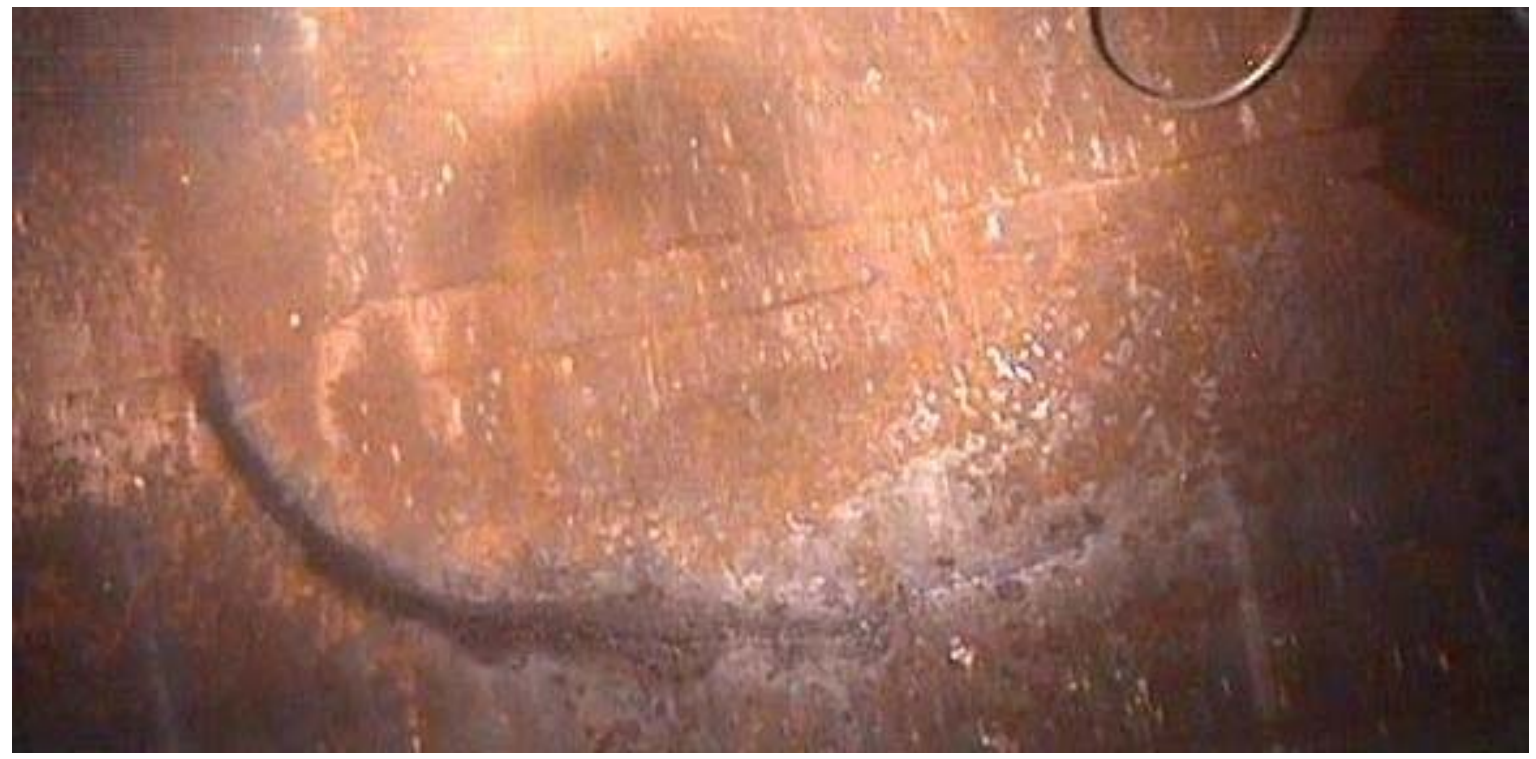

The figure above shows the bleed-out from the portion of the crack that is open to the outside $(100 \%$ through wall). There appears to be distortion at the OD beyond the bleed-out area from a portion of the crack that is through-wall, but the opening is sealed to water bleed-out.

Figure 28: Composite of P-scan Images Indication at 207 feet, Middle Horizontal Weld

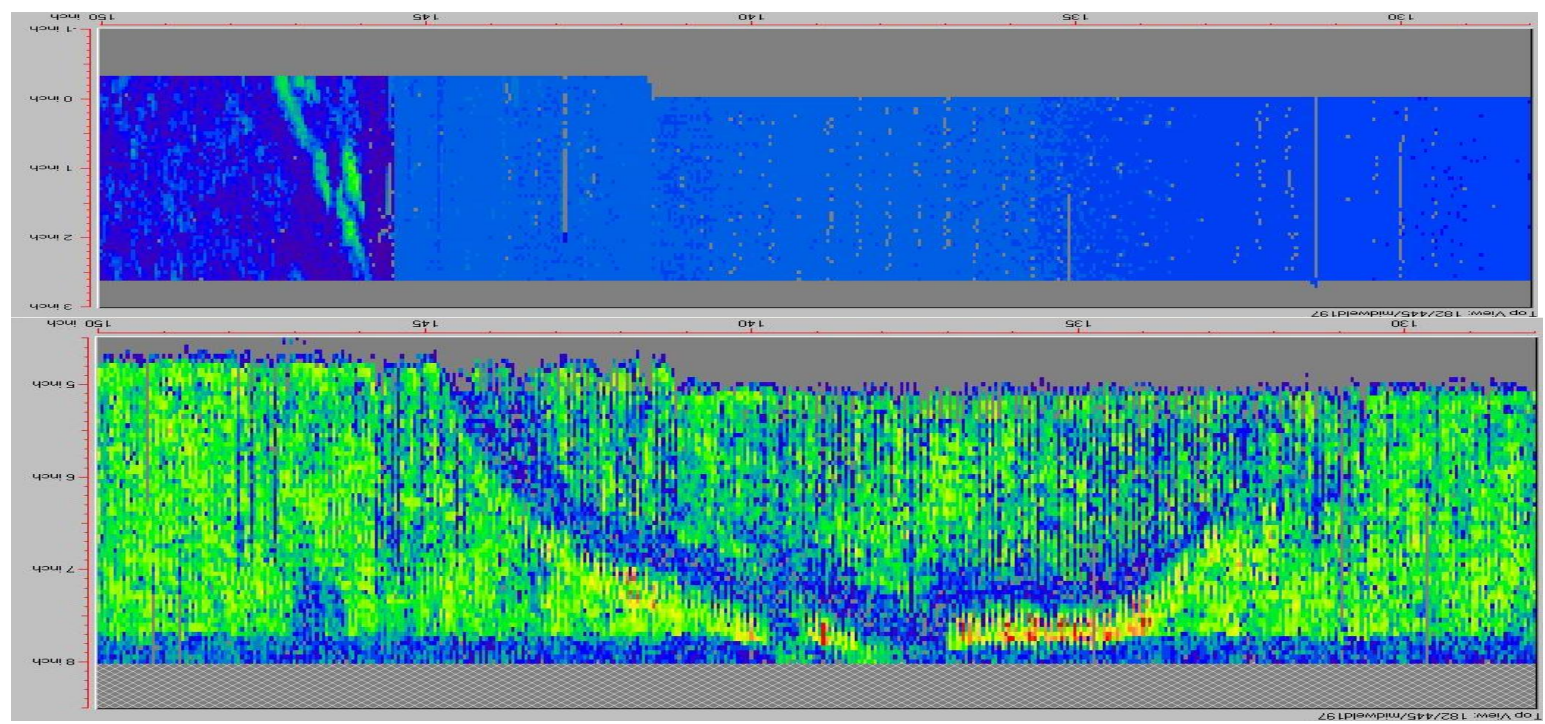

Figure 27 is a composite image including data from both sides with the weld running horizontally through the center (same orientation as pictures). The break in the indication at the center of the arch coincides with a visible break on the surface. The top portion of the image, from the transducer pointing parallel to the weld, shows the branched nature of the crack at the end which consists of multiple short, shallow, parallel cracks. In the bottom portion of the image, from the transducer pointing perpendicular to the weld, the shadow created by the arched crack provides evidence of its length and depth despite the poor orientation to the transducer sound beam. P-scan images were rotated to same orientation as visual image. 
WSRC-TR-2002-00565

\subsection{NDE INSPECTION/REPORT MATRIX}

\begin{tabular}{|c|c|c|c|}
\hline Inspection Item & Date & NDE Data Report & $\begin{array}{c}\text { ISI Review Committee } \\
\text { Report \# }\end{array}$ \\
\hline $\begin{array}{c}\text { Riser 55, Vertical Strip 1, } \\
\text { Upper Plate }\end{array}$ & $8 / 8 / 02$ & $\begin{array}{c}\text { 2002-IR-06-UT-0674 \& } \\
0675\end{array}$ & HLW-STE-2002-00304 \\
\hline $\begin{array}{c}\text { Riser 55, Vertical Strip 1, } \\
\text { Lower Plate }\end{array}$ & $8 / 5 / 02$ & 2002-IR-06-UT-0676 & HLW-STE-2002-00304 \\
\hline $\begin{array}{c}\text { Riser 55, Upper Plate } \\
\text { Vertical Weld Indication }\end{array}$ & $8 / 9 / 02$ & 2002-IR-06-UT-0677 & $\begin{array}{c}\text { HLW-STE-2002-00304 } \\
\text { addendum }\end{array}$ \\
\hline $\begin{array}{c}\text { Riser 107, Vertical Strip 2, } \\
\text { Upper Plate }\end{array}$ & $9 / 04 / 02$ & 2002-IR-06-UT-0743 & HLW-STE-2002-00350 \\
\hline $\begin{array}{c}\text { Riser 107, Vertical Strip 2, } \\
\text { Lower Plate }\end{array}$ & $9 / 5 / 02$ & 2002-IR-06-UT-0744 & HLW-STE-2002-00350 \\
\hline $\begin{array}{l}\text { Riser 107, Middle Plate } \\
\text { Indication }\end{array}$ & $9 / 6 / 02$ & $\begin{array}{c}\text { 2002-IR-06-UT-0745 \& } \\
0746\end{array}$ & HLW-STE-2002-00350 \\
\hline $\begin{array}{c}\text { Riser 182, Vertical Strip 3, } \\
\text { Upper Plate }\end{array}$ & $9 / 16 / 02$ & 2002-IR-06-UT-0934 & HLW-STE-2002-00391 \\
\hline $\begin{array}{c}\text { Riser 182, Vertical Strip 3, } \\
\text { Lower Plate }\end{array}$ & 9/17/02 & 2002-IR-06-UT-0935 & HLW-STE-2002-00391 \\
\hline $\begin{array}{l}\text { Riser 182, Vertical Strip 3, } \\
\text { Indication at Bottom }\end{array}$ & $9 / 17 / 02$ & 2002-IR-06-UT-0943 & HLW-STE-2002-00391 \\
\hline $\begin{array}{l}\text { Riser 182, Middle Weld } \\
\text { Indication@172, }\end{array}$ & $10 / 2 / 02$ & 2002-IR-06-UT-0938 & HLW-STE-2002-00391 \\
\hline $\begin{array}{l}\text { Riser 182, Middle Weld } \\
\text { 183-195' and Indication } \\
\text { @192' }\end{array}$ & $10 / 21 / 02$ & 2002-IR-06-UT-0939 & HLW-STE-2002-00391 \\
\hline $\begin{array}{l}\text { Riser 182, Middle Weld } \\
171-180 \text { ' }\end{array}$ & $10 / 15 / 02$ & 2002-IR-06-UT-0940 & HLW-STE-2002-00391 \\
\hline $\begin{array}{l}\text { Riser 182, Middle Weld } \\
\text { 196-208' and Indication } \\
\text { @207' }\end{array}$ & $10 / 23 / 02$ & 2002-IR-06-UT-0941 & HLW-STE-2002-00391 \\
\hline $\begin{array}{l}\text { Riser 182, Lower Plate } \\
\text { Vertical weld @175, }\end{array}$ & $10 / 17 / 02$ & 2002-IR-06-UT-0942 & HLW-STE-2002-00391 \\
\hline $\begin{array}{c}\text { East Riser (197), Vertical } \\
\text { Strip 4, Upper Plate }\end{array}$ & $9 / 19 / 02$ & 2002-IR-06-UT-0936 & HLW-STE-2002-00391 \\
\hline $\begin{array}{c}\text { East Riser (197), Vertical } \\
\text { Strip 4, Lower Plate }\end{array}$ & $9 / 19 / 02$ & 2002-IR-06-UT-0937 & HLW-STE-2002-00391 \\
\hline
\end{tabular}




\section{REFERENCES}

${ }^{i}$ B. J. Wiersma, K. H. Subramanian., et.al., "In-Service Inspection Program for High Level Waste Tanks," WSRC-TR-2002-00061, February, 2002.

ii Bandyopadhyay, K., Bush, S., Kassir, M., et.al., "Guidelines for Development of Structural Integrity Programs for DOE High Level waste Storage Tanks,” BNL-52527, January 1997.

iii B. J. Wiersma, "A Structural Impact Assessment of Flaws Detected During Ultrasonic Examination of Tank 15", WSRC-TR-2002-00590, December, 2002.

${ }^{\text {iv }}$ R. L. Shanks, “CSTE UT Inspection Plan for Tank 15” HLW-STE-2002-00258, August, 2002.

v J. B. Elder, "Procedure and Equipment Qualification” TSD-NDE-20020726, December, 2002.

${ }^{v i}$ R. S. Waltz, W. R. West, “Annual Radioactive Waste Tank Inspection Program - 2000," WSRC-TR-200100149, May 2001

vii T. B. Edwards, "An Assessment of the Uncertainty of Historical Wall Thickness Measurements for SRS Waste Tanks (U)" WSRC-TR-2002-00130, March 2002 